NBER WORKING PAPER SERIES

\title{
IMPORT COMPETITION, HETEROGENEOUS PREFERENCES OF MANAGERS, AND PRODUCTIVITY
}

\author{
Cheng Chen \\ Claudia Steinwender \\ Working Paper 25539 \\ http://www.nber.org/papers/w25539 \\ NATIONAL BUREAU OF ECONOMIC RESEARCH \\ 1050 Massachusetts Avenue \\ Cambridge, MA 02138 \\ February 2019, Revised August 2021
}

We thank our editor Mary Amiti, two anonymous referees, Laura Alfaro, Pol Antràs, Morten Bennedsen, Richard Blundell, Davin Chor, David Dorn, Taiji Furusawa, Luis Garicano, Matthew Grant, Gene Grossman, Oliver Hart, Réka Juhász, Yao Lu, Hong Luo, Hong Ma, Dávid Nagy, Gianmarco Ottaviano, Nina Pavcnik, Steve Pischke, Andrea Prat, Benjamin Pugsley, Steve Redding, Raffaella Sadun, Antoinette Schoar, Pian Shu, Jagadeesh Sivadasan, Chang Sun, Meredith Startz, Heiwai Tang, Stephen Terry, John van Reenen, Jin Wang and Daniel Xu, as well as seminar participants at various institutions for their comments. Chen acknowledges financial support from the University of Hong Kong and from Hong Kong General Research Fund (project code: 17507916), and Steinwender acknowledges financial support from McKinsey \& Co. for acquiring the data. The views expressed herein are those of the authors and do not necessarily reflect the views of the National Bureau of Economic Research.

NBER working papers are circulated for discussion and comment purposes. They have not been peer-reviewed or been subject to the review by the NBER Board of Directors that accompanies official NBER publications.

(C) 2019 by Cheng Chen and Claudia Steinwender. All rights reserved. Short sections of text, not to exceed two paragraphs, may be quoted without explicit permission provided that full credit, including $\odot$ notice, is given to the source. 
Import Competition, Heterogeneous Preferences of Managers, and Productivity

Cheng Chen and Claudia Steinwender

NBER Working Paper No. 25539

February 2019, Revised August 2021

JEL No. F13,F14,F61,O31

\begin{abstract}
$\underline{\text { ABSTRACT }}$
When managers have objectives beyond maximizing monetary profits, inefficiencies may arise. An increase in competition may then force managers to improve the productivity of the firm in order to ensure survival. While this hypothesis has received ample theoretical attention, empirical evidence is scarce, mainly because preferences of managers are typically unobserved. In this paper, we exploit the fact that a large literature has documented specific non-monetary preferences of family managers. Using Spanish firm-level data, we compare how family-managed and professionally-managed firms react to import competition shocks. We find that import competition leads to productivity increases in family-managed firms that are initially unproductive. Productivity improvements are driven by family management as opposed to family ownership or non-managing family members. Furthermore, we show that these managers increase efficiency by reducing material usage, which is consistent with them trying to increase their short-term cash flow in order to survive. Finally, productivity improvements seem to be particularly pronounced in multi-generational family firms.
\end{abstract}

\title{
Cheng Chen
}

John E. Walker Department of Economics

College of Business

Clemson University

Clemson, SC 29634

and Faculty of Business and Economics, The University of Hong Kong

chencheng1983613@gmail.com

Claudia Steinwender

MIT Sloan School of Management

100 Main Street, E62-521

Cambridge, MA 02142

and NBER

csteinwe@mit.edu 


\section{Introduction}

How competition affects firm-level productivity and innovation is a central question in economics. A theoretical literature dating back at least to Leibenstein (1966) has shown that the role of the manager is critical. In particular, when a manager has preferences that include private benefits and costs that go beyond monetary profits, a so called X-inefficiency may arise. In such a case, as competition increases the bankruptcy risk of a firm, a manager may cut "slack" and make the firm more productive to ensure survival (e.g., Hart, 1983; Hermalin, 1992; Schmidt, 1997; Raith, 2003).

While this "preference hypothesis" has received ample theoretical attention, empirical evidence is relatively scarce (e.g., Schmitz Jr, 2005). This is due to the fact that researchers typically do not observe variation in the preferences of managers. In this paper we exploit a finding from the literature on family firms: family managers have been shown to have distinct preferences that include non-monetary private benefits that are lost when the firm ceases to exist. ${ }^{1}$ In line with this motivation, family managers in Spain report that their most important strategic objective is survival, and their main challenge is dealing with increased competition. $^{2}$

We would therefore expect family firms in particular to improve efficiency when faced with increased competition. Anecdotes suggest this may be the case. For example, the thirdgeneration family CEO of US-manufacturer Watlow explains the reason for adopting lean production principles to eliminate waste as: "A competitive environment forced us to figure out how to lower our costs while also better engaging our people."3 Similarly, one of the authors learned in a conversation with a successful European family firm that the family manager shied away from re-organizing the shop floor for additional efficiency gains while

\footnotetext{
${ }^{1}$ For example, family managers care about building a legacy or creating and sustaining the firm for their descendants. Family managers also take strong pride in their firm and are able to use the firm's resources for personal purposes or to provide jobs for relatives (e.g., Demsetz and Lehn (1985); Bertrand and Mullainathan (2003); Bandiera, Guiso, Prat, and Sadun (2014); Hurst and Pugsley (2011); Bertrand and Schoar (2006); Belenzon, Chatterji, and Daley (2014); Bandiera, Prat, and Sadun (2014)). All of these examples generate a specific non-monetary private benefit for the family manager, which is lost when the firm ceases to exist.

${ }^{2}$ In a survey implemented by the Spanish Instituto de La Empresa Familiar that asks family firms about their main strategic objectives, the most frequent answer by a large margin is guaranteeing the survival of the firm (69.1\%), followed by increasing the profits of the firm (48.7\%) (Instituto de la Empresa Familiar, 2018). In another survey, $51 \%$ of family firms report that increasing competition is their main challenge; the second most frequent answer is the war for talent (40\%) (KPMG, 2017).

${ }^{3}$ https://www.watlow.com/about-watlow/working-at-watlow (accessed Dec 20, 2019).
} 
the company was profitable, but would do so if increased competition threatened long-term survival.

In the empirical part of this paper we examine systematically how family and professional managers react to a shock to import competition, using Spanish firm-level data between 1993 and 2007. The Spanish context and data present a unique scenario to test whether managerial preferences affect the productivity response to competition. First, the Spanish data set reports family management versus professional management for family owned firms. Family management can coincide with family ownership, but the Spanish data allows us to differentiate between the two. Second, there were large increases in import competition, e.g., driven by increased European integration and the unprecedented increase in Chinese exports. ${ }^{4}$ Importantly, we exploit a unique feature of the Spanish setting: Spain's import tariffs are set at the EU level and therefore arguably exogenous to Spanish firms.

Our main empirical specification studies how changes in tariffs affect changes in the labor productivity of Spanish firms, distinguishing between family- and professionally-managed (i.e., non-family-managed) firms. We allow the effects to differ by the initial productivity of firms so as not to confound the effects of family management with the effects of initial productivity. ${ }^{5}$ In essence, we are comparing the productivity response of firms with and without family managers, holding their initial productivity constant.

Our empirical analysis uncovers a specific, robust pattern of heterogeneous responses. After a reduction in import tariffs, the family firms in the left tail of the initial productivity distribution (i.e., initially unproductive firms) increase productivity, while we do not observe significant changes in the productivity of initially productive family firms or professionallymanaged firms. The key theoretical mechanism we are able to identify is that increased product market competition (due to lower tariffs) incentivizes managers in firms that are more likely to exit (i.e., initially unproductive firms) and have X-inefficiency (i.e., family

\footnotetext{
${ }^{4}$ Similar shocks have been experienced by, e.g., the US (Autor, Dorn, and Hanson, 2013; Hombert and Matray, 2017), Canada (Kueng, Li, and Yang, 2017), the UK (Bloom, Draca, and Van Reenen, 2016), South Korea (Ahn, Han, and Huang, 2018), Vietnam (Dang, 2017), Peru (Medina, 2018).

${ }^{5}$ Studies focusing on heterogeneous effects of import competition have often found positive effects to be present in large or productive firms, while effects for small or less productive firms have been found to be smaller, or even negative. For some examples, see Muendler, 2004; Schor, 2004; Fernandes, 2007; Gorodnichenko, Svejnar, and Terrell, 2010; Iacovone, 2012; Iacovone, Keller, and Rauch, 2011; Fernandes and Paunov, 2009; Autor, Dorn, Hanson, Pisano, and Shu, 2017; Bombardini, Li, and Wang, 2017; Xu and Gong, 2017; Ahn et al., 2018.
} 
firms) to exert more effort in order to prevent their firms from going bankrupt.

In robustness checks we rule out two alternative explanations. First, we verify that family management, rather than other characteristics of family-managed firms (e.g., firm size, R\&D intensity, or capital intensity) drive our results. We also show that our results are not driven by family ownership or by a switch towards professional managers. While we are admittedly not able to exploit exogenous variation in family management, excluding a large number of alternative explanations makes it unlikely that characteristics other than family management are generating our results. Second, we show that the productivity response is not driven by improved access to imported inputs or foreign markets. In addition, the affected firms do not show significant changes in the volume of imported technologies or exports.

We provide a stylized model to rationalize our empirical findings. In the model, all managers care about the profits of the firm, but family managers derive additional utility from being a part of the family firm which captures the private benefits to the family manager discussed above. Importantly, they lose this additional utility if the firm goes bankrupt. Managers can increase the initial productivity draw of the firm by exerting effort, which entails private costs. If the initial productivity of the firm is far from the exit cutoff, professional and family managers choose the same level of effort, which increases in the initial productivity. However, if the initial productivity of a firm is low, family managers exert effort in order to avoid bankruptcy by making the firm break even, while professional managers let the firm go bankrupt. When an import competition shock hits the economy, potential profits of all firms fall. This increases the bankruptcy risk for unproductive firms. Since family managers care more about the existence of their firms, they exert extra effort to avoid bankruptcy.

In addition to rationalizing our key empirical findings, our model yields additional predictions that match the data. First, we show that the productivity increases in the data are driven by increases in efficiency improvements rather than innovation, which is in line with the motive of managers to increase cash flow in short run in order to ensure survival. Second, the empirical findings are particularly strong for firms with a larger number of family managers, which are more likely to be multi-generational businesses for which the mechanism is most relevant. Finally, our model predicts that unproductive non-family firms are more likely to exit than family firms; and we find empirical support for this prediction.

Our paper contributes to the literature on how trade liberalization affects firm productiv- 
ity and innovation. ${ }^{6}$ While papers focusing on the effect of access to export markets (e.g., Lileeva and Trefler, 2010; Bustos, 2011; Coelli, Moxnes, and Ulltveit-Moe, 2018; Mayer, Melitz, and Ottaviano, 2016) or access to intermediate inputs (e.g., Amiti and Konings, 2007; Brandt, Van Biesebroeck, Wang, and Zhang, 2017; Fieler and Harrison, 2018) tend to find positive effects on innovation and productivity, studies focusing on the effect of import competition have found more divided and heterogeneous effects on firms (e.g., Pavcnik (2002); Amiti and Konings (2007); Bloom et al. (2016); Autor et al. (2017); Bombardini et al. (2017)). In this paper we focus on a novel dimension of heterogeneity, family management, that may affect productivity responses to trade liberalization. Given that most developing countries host a large number of family firms and have experienced major trade liberalizations, studying this dimension of heterogeneity seems to be particularly important.

We also contribute to the literature that studies the effect of competition on firm productivity and management practices via $\mathrm{X}$-inefficiencies. A common prediction is that intensified market competition leads to a higher bankruptcy risk and reduces managerial slack, as managers are willing to exert more effort in order to avoid potential bankruptcy (e.g., Hart, 1983; Hermalin, 1992; Schmidt, 1997; Raith, 2003; Wu, 2011). Recent work on management practices (e.g., Bloom and Van Reenen, 2007, 2010; Bloom, Eifert, Mahajan, McKenzie, and Roberts, 2013) finds that tougher market competition incentivizes firms to improve management practices, by using cross-sectional survey data on management practices. Beyond this, a growing literature emphasizes the role of managers and management practices in international trade (e.g., Caliendo and Rossi-Hansberg, 2012; Chakraborty and Raveh, 2018; Bloom, Manova, Van Reenen, Sun, and Yu, 2018). We contribute to this literature empirically by exploring how an exogenous shock affects firms' productivity depending on the preferences of managers.

Finally, we contribute to the literature on family firms. ${ }^{7}$ Family firms are a widespread

\footnotetext{
${ }^{6}$ For a review of this literature, see Shu and Steinwender (2019). Besides within-firm productivity improvements, the literature also emphasizes that trade liberalization may increase aggregate productivity by reallocating resources towards the most efficient firms (e.g., Pavcnik, 2002). A related literature examines how foreign direct investment affects the productivity of firms (e.g., Guadalupe, Kuzmina, and Thomas, 2012).

${ }^{7}$ E.g., Shleifer and Vishny (1986); Morck, Shleifer, and Vishny (1988); Shleifer and Vishny (1997); Morck, Stangeland, and Yeung (2000); Anderson and Reeb (2003); Pérez-González (2006); Villalonga and Amit (2006); Bennedsen, Nielsen, Perez-Gonzalez, and Wolfenzon (2007); Gomez-Mejia, Haynes, Nunez-Nickel, Jacobson, and Moyano-Fuentes (2007); Bertrand, Johnson, Samphantharak, and Schoar (2008); Mullins and Schoar (2016).
} 
economic phenomenon in developed, but especially in developing countries. ${ }^{8}$ Given their ubiquity, it is important to understand the decision making process of family managers better. Most papers in this literature document that family firms, and especially family-managed firms, perform worse than non-family firms. ${ }^{9}$ We highlight how economic forces, specifically increased competition, can incentivize unproductive family firms to become more productive.

\section{Data description}

We use panel data from a Spanish survey of manufacturing firms (ESEE; Encuesta Sobre Estrategias Empresariales) that is collected by the Fundación SEPI, a foundation affiliated with the Spanish Ministry of Finance and Public Administration. ${ }^{10}$ The survey is designed to cover a representative sample of Spanish manufacturing firms and includes around 1,800 firms per year. The survey started in 1990: In this year, participation of firms with more than 200 employees was required, while firms with more than 10 but fewer than 200 employees were sampled via a stratified sampling approach based on detailed size and industry categories. ${ }^{11}$ After that, SEPI made a great effort to replace non-responding and exiting firms with firms from the same size and industry category to ensure the continuing representativeness of the sample. ${ }^{12}$ Since the data on capital is incomplete before 1993 (e.g., information on intangible capital and depreciation is not available) and the financial crisis in 2007 might have brought about confounding shocks, we focus on the years between 1993 and 2007,

\footnotetext{
${ }^{8}$ For example, $15 \%$ of the American Fortune Global 500 firms are family firms. In Europe, $40 \%$ of large, listed companies are controlled by families. See http://www.economist.com/news/leaders/21629376-thereare-important-lessons-be-learnt-surprising-resilience-family-firms-relative. For developing countries, out of large ( $>\$ 1$ billion) firms, $85 \%$ are family run in South-East Asia, 75\% in Latin America, $67 \%$ in India, and around 65\% in the Middle East. See http://www.economist.com/news/business/21629385-companiescontrolled-founding-families-remain-surprisingly-important-and-look-set-stay.

${ }^{9}$ E.g., Morck et al. (2000); Bertrand and Schoar (2006); Pérez-González (2006); Villalonga and Amit (2006); Bennedsen et al. (2007); Bloom and Van Reenen (2007); Bandiera, Guiso, Prat, and Sadun (2011); Bandiera et al. (2014); Mullins and Schoar (2016); Lemos, Scur, et al. (2016). There are, however, papers in this literature arguing that family ownership is associated with better firm performance (e.g., Anderson and Reeb, 2003). For example, family ownership can facilitate monitoring inside the firm (Demsetz and Lehn, 1985; Burkart, Panunzi, and Shleifer, 2003) and reduce short-termism (Stein, 1988, 1989; James, 1999).

${ }^{10}$ For more information, see https://www.fundacionsepi.es/investigacion/esee/en/spresentacion.asp.

${ }^{11}$ Our results are robust to using sampling weights based on the Spanish Social Security Census that have been provided by Fundación SEPI for 2005.

${ }^{12}$ In Section C. 3 of the online appendix we show that our empirical results are robust to different ways of dealing with non-responses.
} 
covering a total of around 4,000 observed firms.

The advantage of the Spanish data set is that it provides very rich information on several dimensions that are important for our empirical analysis. ${ }^{13}$

Family firms. We distinguish between family-managed and professionally-managed firms because the survey includes a variable that gives the number of "owners and working relatives who hold managing positions." 14 We classify firms as family-managed firms (or family firms, in short) if this number is bigger than or equal to one in the first year of our sample, 1993. We use the first year of the sample for this definition in order to avoid a potentially endogenous definition of management type that responds to changes in competition. ${ }^{15}$

Family firms are prevalent in Spain: Table 1 shows that $41 \%$ of our observations are family firms. $57 \%$ of family firms in our sample have just one family manager, and none of the firms have more than seven family managers (see online appendix for a histogram). Consistent with the literature, family firms are on average smaller (both in terms of sales and employment), have lower productivity, and spend less on R\&D. ${ }^{16}$ Some of this difference is explained by family firms operating in different industries, but significant differences remain even when we control for industry fixed effects, as the last column in Table 1 shows.

The share of family firms ranges from $17 \%$ to $69 \%$ across different industries (see Figure 1 in the online appendix). In Table E.5 of the online appendix we show that tariff changes are uncorrelated with the initial share of family firms, changes in the share of family firms across industries, or with the number of family managers within a firm. Family management is relatively persistent: 74\% of family-managed firms in 1993 are still family-managed in 2007. This finding is consistent with earlier work on Spanish family firms using different data (Gallo and Pont, 1989).

Our main regressions use information on family members in managing positions. The data set also includes information about the number of family members in non-managing positions, which we use in a placebo test to differentiate family management from other nonmanagerial aspects of family businesses. Furthermore we use a variable indicating whether

\footnotetext{
${ }^{13}$ Note that additional details regarding the construction of our variables can be found in the online appendix.

${ }^{14}$ Note that an owner is not necessarily a majority owner (this is not clearly specified in the survey) and a founder is not necessarily an owner.

${ }^{15}$ In a robustness check we look at whether changes in management explain the productivity response.

${ }^{16}$ Figure D.4 in the online appendix shows the initial productivity distribution of family and non-family firms. While the average productivity of non-family firms is higher, there is a significant overlap in the distributions.
} 
the firm is controlled by a family group as an indicator for family ownership and thereby distinguish between family-owned and family-managed, and family-owned but professionallymanaged firms. This variable, however, is available for one year at the end of our sample, which is why we use it only in robustness checks.

Productivity. We use labor productivity as our main measure of productivity as it is transparent and can be directly observed in the data. Since we do not want to interpret changes in output or input prices as changes in productivity, we exploit the fact that the Spanish firm-level survey provides firm-specific deflators for inputs and outputs. ${ }^{17}$ Firms are asked by what percentage the sales price of its products and the purchasing price of its intermediate inputs and services have changed compared to the previous year. The price changes are supposed to be calculated as a weighted average across various final products and markets (for output prices) and a weighted average across various intermediate inputs, energy consumption, and purchased services (for input prices). We use these price changes to deflate output and intermediate inputs at the firm level (instead of using industry-wide deflators). Overall, our measure of labor productivity is therefore given as deflated sales minus deflated intermediate inputs divided by employment. ${ }^{18}$

Labor productivity does not exclude the contribution of capital to total output from the productivity measure; and productivity changes might be driven by changes in the capital stock. In robustness checks, we use the Olley and Pakes (1996)-type proxy estimator approach augmented with a De Loecker $(2007 ; 2013)$-type correction. Specifically, we allow the management type (i.e., family management or professional management), import and export tariffs to directly affect the evolution of firm productivity to estimate firm-level total factor productivity (TFP). Practically, we use a polynomial of the management type, the (import and export) tariffs, investment and capital stock to proxy for the unobserved TFP. As a result, we use this polynomial to run regressions in all three stages of the Olley and Pakes

\footnotetext{
${ }^{17}$ Ornaghi (2006) first demonstrated the usefulness of this feature in the Spanish firm-level data. The importance of distinguishing between productivity and price changes has been noted in e.g., De Loecker (2011) and Beveren (2012).

${ }^{18}$ Notice that this price correction can only be applied to changes in prices, and not to the cross-sectional differences in prices across firms. We normalize the price indices for each firm to be equal to 1 in 1993 (our base year), which means that we compare firms with different initial values of productivity in 1993 when we interact import competition with initial productivity further below. This is consistent with our intentions: the cross-sectional interaction term is supposed to capture increased exit probability, for which both prices and physical productivity are relevant. However, when we look at responses of firms to shocks, we are able to tell apart changes in physical productivity from changes in prices.
} 
(1996)-type estimation (additional details are provided in the online appendix).

Tariff data. This paper exploits variations in industry-specific import tariffs over time. We use tariffs that the EU imposes on imports from the rest of the world ("import tariffs") to construct our main regressor. We use MFN tariffs from TRAINS (provided by UNCTAD) accessed via the WITS software provided by the World Bank. ${ }^{19}$ We use the weighted average of the import tariff in each product category (ISIC Rev. 3; 244 product categories) and aggregate them to the NACECLIO industries that the Spanish data uses (20 NACECLIO categories $^{20}$ ) by using Spanish trade shares in 1993 (to avoid endogeneity of the weights). Our results are robust to using trade shares from the previous year to calculate the industrylevel tariffs. For robustness checks we calculate average tariffs that other countries impose on exports from the EU ("export tariffs") as an indicator for export opportunities with the same methodology; and import tariffs on the inputs ("input tariffs") of an industry based on Spanish input-output tables to control for changed access to imported inputs.

The resulting import tariffs are shown in Figure 1. Tariffs fell over time, especially during the 1990s. Important trade liberalization episodes that occurred during the sample period include several EU enlargement episodes (e.g., also studied by Berger and Nitsch, 2008; Bergin and Lin, 2012; Brouwer, Paap, and Viaene, 2008) and China's accession to the WTO in 2001 (also studied in Bloom et al., 2016; Autor et al., 2013). A large heterogeneity of tariffs across industries is also visible. Beverages, food/tobacco, meat related products, and textiles all started with the highest tariffs. While tariffs dropped for food and drink related industries, tariffs on textiles fell very little. Tariffs for leather/fur/footwear and vehicles also changed little and remain on the higher end. Summary statistics of the tariff changes are given in Table E.1 of the online appendix.

\section{Empirical strategy}

We start by estimating the effects of import competition separately for the set of familymanaged and professionally-managed firms. We then combine the separate regressions into a

\footnotetext{
${ }^{19} \mathrm{http}: / /$ wits.worldbank.org/wits/

${ }^{20}$ The 20 industries are: meat related products; food and tobacco; beverage; textiles and clothing; leather, fur, and footwear; timber; paper; printing and publishing; chemicals; plastic and rubber products; nonmetal mineral products; basic metal products; fabricated metal products; industrial and agricultural equipment; office machinery, data processing, precision instruments and similar; electric materials and accessories; vehicles and accessories; other transportation materials; furniture; miscellaneous.
} 
pooled regression, which has three advantages: First, it allows us to test whether coefficients are significantly different across family and non-family firms. Second, it allows us to check whether our results are robust to adding industry-times-year fixed effects. Third, it allows us to more efficiently conduct a variety of other robustness checks.

Separate regressions. We begin with an OLS regression of log productivity changes $\Delta \ln \left(\right.$ labprod $\left._{i t}\right)$ on changes in import competition $\Delta I M P_{s t}$ separately for family and nonfamily firms. We allow for a potential heterogeneous effect depending on the firm's log productivity in our base year $1993, \ln \left(\right.$ labprod $\left.93_{i}\right)$, in line with literature on heterogeneous firms and trade inspired by Melitz (2003),

$$
\begin{aligned}
\Delta \ln \left(\text { labprod }_{i t}\right)= & \beta_{1} \Delta I M P_{\text {st }}+\beta_{2}\left(\Delta I M P_{\text {st }} \cdot \ln \left({\text { labprod } \left.\left.93_{i}\right)\right)}\right)\right. \\
& +\beta_{3} \cdot \ln \left(\text { labprod } 93_{i}\right)+\text { yearFE }+ \text { industryFE }+\eta_{i t}
\end{aligned}
$$

where $i$ denotes firm, $s$ denotes industry, and $t$ denotes year.

A few things should be noted: We add the interaction of import competition with initial productivity because we are interested in heterogeneous effects for firms that are initially unproductive versus those that are initially productive. Notice, however, that the magnitude of coefficient $\beta_{1}$ does not directly reveal the effect of import competition on productivity for initially unproductive family firms as there are no firms with zero initial productivity. Similarly, the coefficient $\beta_{2}$ tells us how the effect changes as initial productivity increases, but it does not tell us which sign the effects have for initially very productive firms. For this reason we calculate the marginal effects of import competition for firms at the 10th percentile (i.e., initially unproductive) and for firms at the 90th percentile (i.e., initially productive) of the initial productivity distribution. ${ }^{21}$ For robustness, we also estimate the interaction effect non-linearly with respect to different percentiles. However, it turns out that a linear approximation works quite well.

For easier interpretation we use the negative of the industry- and year-specific EU import tariff, denoted as $I M P_{s t}$, as our exogenous variation in import competition. This means

\footnotetext{
${ }^{21}$ More specifically, we calculate marginal effects as $\frac{\partial \Delta \ln \left(\text { labprod }_{i t}\right)}{\partial \Delta I M P_{s t}}=\beta_{1}+\beta_{2} \ln \left(\right.$ labprod $\left._{9} 3_{i}\right)$ and evaluate them at the 10th and 90th percentile of the initial productivity distribution (across all firms; i.e., including both family and non-family firms).
} 
when $I M P_{s t}$ increases, import competition increases due to a reduction in import tariffs. In general, it is not always clear whether tariff changes can be interpreted as exogenous to firms and industries as large companies often try to influence policy makers in order to obtain favorable tariffs. However, in the Spanish case tariffs are negotiated at the European level and it is less likely that Spanish firms are able to influence European decision making. Furthermore, many tariff changes are part of a larger political process (e.g., the EU enlargement or China's WTO accession) and therefore likely out of the control of specific Spanish firms.

Our specification allows for year fixed effects to absorb macroeconomic shocks. Since the model is in first differences, any time-invariant firm or industry characteristics are absorbed as firm fixed effects in levels drop out in the first differences specification. ${ }^{22}$ We follow Autor et al. (2017) and make the empirical specification more demanding by adding industry-level fixed effects to the estimation equation in first differences, allowing for industry specific time trends. Historically, import tariffs have fallen while productivity has increased at the industry level. These correlated trends should not be interpreted as causal evidence of a productivity response to increased import competition.

Finally, all standard errors are two-way clustered at the firm level (to allow for autocorrelation within a firm over time) and industry-year level (to allow for correlation across firms in the same industry).

Pooled regressions. Our main specification is a pooled OLS regression of family and non-family firms with triple interaction terms that allow for differential effects of import competition depending on a firm's management type (family vs. non-family) and initial productivity. The resulting, fully saturated regression equation is:

\footnotetext{
${ }^{22}$ The estimation in first differences (FD) has two additional advantages over an equivalent fixed effects (FE) regression. First, it imposes slightly weaker exogeneity assumptions (Wooldridge, 2010, p. 316). Second, it uses the variation in the data that we believe is most relevant for modelling managerial behavior, i.e., year-onyear changes in tariffs versus deviations of tariffs from long run means across past and future, unknown, values. In line with this reasoning, the marginal effect of import competition on the productivity of unproductive family versus non-family managers is smaller and less precisely estimated in a fixed effects regression.
} 


$$
\begin{aligned}
& \Delta \ln \left(\text { labprod }_{i t}\right)=\beta_{1} \cdot \Delta I M P_{s t}+\beta_{2} \cdot \Delta I M P_{s t} \cdot \ln \left(\text { labprod } 93_{i}\right) \\
& +\beta_{3} \cdot \Delta I M P_{s t} \cdot F A M 93_{i}+\beta_{4} \cdot \Delta I M P_{s t} \cdot \ln \left(\text { labprod } 93_{i}\right) \cdot F A M 93_{i} \\
& +\beta_{5} \cdot F A M 93_{i}+\beta_{6} \cdot \ln \left(\text { labprod } 93_{i}\right) \cdot F A M 93_{i}+\beta_{7} \cdot \ln \left({\text { labprod } \left.93_{i}\right)}\right) \\
& + \text { yearFE } F A M 93_{i}+\text { industryFE } F A M 93_{i}+\eta_{i t}
\end{aligned}
$$

We allow for family-firm-specific year and industry fixed effects. This ensures that all coefficients in this regression are identical to the coefficients obtained from the separate regressions for family and non-family firms. For example, coefficients $\beta_{1}$ and $\beta_{2}$ estimate the effects of import competition for non-family firms, allowing for a differential effect by initial productivity. Importantly, the advantage of the pooled regression is that it allows us to test whether the estimated effect on family firms is significantly different from that of non-family firms, which is estimated by coefficients $\beta_{3}$ and $\beta_{4}$ (again allowing for a differential effect by initial productivity). Since we are interested in the effect on the initially least (p10) and most (p90) productive firms, we compute marginal effects as discussed above. $^{23}$ In addition, we are able to compute marginal differential effects in these regressions. By focusing on these marginal differential effects we are implicitly implementing two difference-in-differences specifications (family versus non-family firms; before and after an import competition shock): one for initially unproductive and one for initially productive firms, which we will report separately. ${ }^{24}$ As this is the most stringent specification, we are going to focus our interpretation on these estimated effects.

Additional benefits of the pooled regression are that we are able to add industry-timesyear fixed effects; and that we are able to show a large number of robustness checks in a simple and space-saving way.

\footnotetext{
${ }^{23}$ More specifically, we calculate the marginal effect for non-family firms as $\left.\frac{\partial \Delta \ln \left(\text { labprod }_{i t}\right)}{\partial \Delta I M P_{s t}}\right|_{F A M 93_{i}=0}=$ $\beta_{1}+\beta_{2} \ln \left({\left.\text { labprod } 93_{i}\right)}_{i}\right.$ and for family-firms as $\left.\frac{\partial \Delta \ln \left(\text { labprod }_{i t}\right)}{\partial \Delta I M P_{s t}}\right|_{F A M 93_{i}=1}=\beta_{1}+\beta_{3}+$ $\left(\beta_{2}+\beta_{4}\right) \ln \left(\right.$ labprod $\left.93_{i}\right)$, substituting in the 10th and 90th percentile of the initial, overall productivity distribution.

${ }^{24}$ The marginal differential effect is given by $\left.\frac{\partial \Delta \ln \left(\text { labprod }_{i t}\right)}{\partial \Delta I M P_{s t}}\right|_{F A M 93_{i}=1}-\left.\frac{\partial \Delta \ln \left(\text { labprod }_{i t}\right)}{\partial \Delta I M P_{s t}}\right|_{F A M 93_{i}=0}=\beta_{3}+$ $\beta_{4} \ln \left(\right.$ labprod $\left.93_{i}\right)$, substituting in the 10th and 90 th percentile of the initial, overall productivity distribution.
} 


\section{Empirical results}

Separate regressions. We start by dividing the sample into family-managed and professionallymanaged firms and estimate the effect on these two samples separately in Table 2. Columns (1) and (5) already reveal that heterogeneity across these different types of firms is important: Import competition has a positive and significant effect on the labor productivity of family firms but a negative and insignificant effect on non-family firms. ${ }^{25}$ Note that this difference is not driven by differences in initial productivity as we control for this.

In columns (2) and (6) we allow for additional heterogeneity with respect to initial productivity. The coefficient on import competition is large and significant for family firms and the effect decreases as the initial productivity of firms increases. Interpreting the raw coefficients is not meaningful, however, as there are no firms in the sample with an initial log productivity of zero. We therefore evaluate the estimated effects for firms at the 10th and 90th percentile of the initial productivity distribution, which are reported in the rows below the coefficients. We can see that import competition has a large and positive effect on the productivity of initially unproductive firms, but this effect fades out and there is an insignificant effect for initially productive firms. When we implement the same exercise using the sample of non-family firms, we see negative effects for both the initially least productive firms and the initially most productive firms. However, all effects are insignificant.

In columns (3) and (7) we add region fixed effects to the regression and in columns (4) and (8) we allow for firm-specific time trends but the results change very little. Overall, there is a very robust, positive productivity response to import competition for initially unproductive family firms. ${ }^{26}$

The magnitude of this effect is sizable. In our preferred specification in column (2) of Table 2, a one percentage point reduction in the import tariff leads to a $4 \%$ increase in labor productivity for the family firms with low initial productivity (10th percentile). Over the sample period, the import tariff fell by 0.295 percentage points per year on average, so the

\footnotetext{
${ }^{25}$ The average effect of import competition on labor productivity across all firms is positive, but insignificant (see Table E.6 in the online appendix). The magnitude is similar to findings in the literature, e.g., Fernandes (2007); Schor (2004); Amiti and Konings (2007).

${ }^{26} \mathrm{We}$ also checked whether there are additional effects to lagged changes in import tariffs but we were not able to find significant effects (see Table E.7 in the online appendix). The immediate response is consistent with the motive to fight against bankruptcy in order to survive another day, which we present in the theoretical part of the paper.
} 
resulting average annual productivity increase is about $1.2 \%$ for the initially least productive family firms. A large annual import tariff reduction (95th percentile), however, would be associated with a $4.7 \%$ labor productivity increase for the initially least productive family firms.

Non-parametric regressions. Regression equation (1) imposes a linear relationship between the initial productivity and productivity changes after an import competition shock hits. The estimation might disguise a non-linear or non-monotonic relationship in the data. In order to check this, we also implement non-parametric versions of regression equation (1) for both types of firms:

$$
\begin{aligned}
\Delta \ln \left(\text { labprod }_{i t}\right)= & \beta_{1} \Delta I M P_{s t}+\sum_{p} \beta_{2 p} \operatorname{Perc} 93_{p i}+\sum_{p} \beta_{3 p}\left(\operatorname{Perc} 93_{p i} \cdot \Delta I M P_{s t}\right) \\
& + \text { yearFE }+ \text { industryFE }+\eta_{i t},
\end{aligned}
$$

where $\operatorname{Perc} 93_{p i}$ are dummy variables for firm $i$ 's position in different percentiles $p$ of the initial productivity distribution. We experiment with different percentiles, using halves, terciles, quartiles, and quintiles.

Figure 2 shows the effects graphically for the case of quintiles. Family firms that are in the bottom two percentiles of the initial productivity distribution respond positively to import competition but the response is smaller and insignificant for more productive firms. The pattern across percentiles suggests that the linear interaction is indeed a good approximation. In contrast, non-family firms respond negatively to import competition but the effect is mostly insignificant. This pattern is consistent across different splits of percentiles of the data (see Table E. 8 in the online appendix).

Pooled regressions. In Table 3 we move to the pooled estimation given in regression equation (2) that estimates the effects jointly for family and non-family firms. Column (1) implements the pooled version of the separate regressions in columns (2) and (6) of Table 2. Using these estimates we can compute marginal effects for non-family and family firms at various points of the initial productivity distribution. Table 3 reports marginal effects at the 10th and 90th percentile of the initial productivity distribution and in Figure 3 we report the results for the entire initial productivity distribution of family and non-family firms. The effect on family firms decreases with firms' initial productivity but it is positive 
and significant even for the median-sized family firms, which indicates that our estimated effect is not just relevant for a handful of unproductive family firms.

More importantly from an identification point of view, however, the pooled regression allows us to test whether the estimated effect is statistically different between family firms and non-family firms. We implement this test in the last rows of Table 3 and see that the effect on the initially least productive family firms is indeed statistically larger than the effect on the initially least productive professionally managed firms. In order to save space and to simplify the exposition, we are going to focus on these two marginal differential effects in following tables.

The remaining columns in Table 3 add a number of different fixed effects to check the robustness of the results. In column (2), we add regional fixed effects (separately for family and non-family firms) to allow for confounding geographic trends. In column (3) we allow for industry*year fixed effects to absorb any industry-year specific heterogeneity that might be correlated with import competition. Taking this step leaves us unable to identify the main effect of import competition but it is reassuring to see that all the interaction terms remain almost unchanged. Turning to the marginal effects, while we cannot estimate the main effects on family or non-family firms in this specification, we can identify the differential effect of interest which is still significant. In column (4) we even control for firm fixed effects, which allows for firm-specific trends in productivity (as the estimating equation is in first differences). In short, our results are robust to including these various fixed effects. ${ }^{27}$ As another robustness check, Figure D.5 in the online appendix shows that our results are not driven by a specific industry, as results are very similar when we drop one industry at a time.

In Table E.9 of the online appendix we provide estimates in which we restrict the sample to the period 1993 to 2000 — as can be seen in Figure 1, this was the period in which the

\footnotetext{
${ }^{27}$ In column (1) of Table E.11 we show that our results also hold when we use one-year lagged labor productivity instead of labor productivity in 1993 as the interaction term. Using lagged productivity instead of productivity in 1993 in principle allows for the inclusion of entering firms later in the sample period. We show that our results are robust to this inclusion in column (2) of Table E.11. However, in our main specifications we prefer to use productivity in the base year, as while we can purge changes in productivity off changes in firm-specific input and output prices, we cannot do this for the levels of productivity in the cross section, and comparing productivity levels across different years is therefore problematic. We tried to adjust for this by using annual productivity percentiles instead of productivity levels in column (2) of Table E.11, but this is of course imperfect. Using initial productivity has two additional advantages: It holds the sample of firms fixed, so we do not have to worry about endogenous sample composition; and it restricts potential anticipatory productivity adjustments.
} 
tariffs decreased most. It is reassuring to see that our estimates are not sensitive to the time horizon, as the results are very similar; if anything, the differential effect for family versus non-family firms is slightly stronger during the early period.

The number of family managers. So far we have compared firms with any family managers with firms that have no family managers. Since our data includes the number of family managers, we can refine our specification and interact the effects with the number of managers. As Table E.10 in the online appendix shows, firms with one family manager increase productivity significantly relative to firms with professional managers. What is more is that the effect is estimated to be increasing in the number of family managers a firm has.

Alternative productivity measures. While labor productivity is a transparent measure, it has one disadvantage: Increases may be driven by capital accumulation. In order to investigate whether this is responsible for our main finding, we implement a structural TFP estimation for robustness. We follow the recent literature by combining the Olley and Pakes (1996)-type proxy estimator approach augmented with a De Loecker (2007; 2013)-type correction that allows for family firms to have different technologies from non-family firms; and the management type and import tariffs to directly affect the evolution of TFP. ${ }^{28}$ Our results are robust to using this TFP measure (see Table E.12 in the online appendix), suggesting that the estimates are driven by increases in productivity rather than increases in capital stock. In the same table we also show that our results are robust to using alternative normalizations in labor productivity (e.g., value added per number of hours worked, or value added divided by total wage bill). In our main analysis we prefer using the simpler labor productivity measure, as it does not depend on the assumptions required for TFP estimation.

\subsection{Robustness checks: family management}

Given that we know family and non-family firms differ across observable and unobservable characteristics, we want to understand whether our estimated effects are driven by family management rather than other, correlated (observed or unobserved) firm characteristics. Since we are not able to use an instrumental variable approach (e.g., as in Bennedsen et al. 2007) that would make it possible for us to compare two identical firms that differ only by management type, we implement several different tests.

Observable firm characteristics. In Table 4 we perform a horse race between family

\footnotetext{
${ }^{28}$ See Section C.1 in the online appendix for a detailed explanation of the TFP estimation procedure.
} 
management and other observable characteristics such as size, R\&D intensity, and capital intensity, allowing for productivity changes to depend on initial productivity just as in our baseline specification. ${ }^{29}$ Column (1) repeats our baseline specification and in column (2) we add an interaction term between import competition and the initial sales of the firm. This specification allows the effects to differ across firms with different initial sizes and helps us distinguish between the effects of family firms versus the effects of firm size. Interestingly, the estimates on family firms are not affected by this inclusion and the coefficients on sales are not significant, suggesting that family management rather than size matters. In column (3) we conduct the same exercise using initial employment as an alternative size measure with the same results. In column (4) we perform the same exercise with initial R\&D intensity and in column (5) we allow the effect to vary by initial capital intensity. Neither inclusion has an impact on the effects of family management. In fact, the differential marginal effects for family firms at the lowest percentile are remarkably similar in magnitude. This is robust to adding all alternative characteristics together in column (6).

As an alternative method, we use two propensity score matching (PSM) techniques (inverse propensity score re-weighting and nearest neighbor matching) using firm's initial TFP, sales, employment, and exporting status. Table E.13 of the online appendix reports the propensity score estimation, and Figure D.6 in the online appendix illustrates that the area of common support comprises of almost the entire range of propensity scores. Both PSM methods are successful in generating similar distributions of TFP, sales and employment for family and non-family firms (see Figure D.7 in the online appendix). Table E.14 in the online appendix shows that our empirical results are robust to using either method (see Section C.2 in the online appendix for details on the methodology).

Non-managing family members. Next, we explore more intangible characteristics of family-managed firms. Since we also observe the number of family members in nonmanaging positions, we can check whether those employees affect productivity in a way similar to that of managing family members. If this is the case, we are likely measuring the effects of some other more general characteristics of firms that are associated with families rather than the specific effect of family management. We perform a horse race in column (2) of Table 5 and test whether our effects are driven by family members in managing versus

\footnotetext{
${ }^{29}$ Note that we do not need to test against differences in productivity as our baseline estimates already control for initial productivity.
} 
non-managing positions. Specifically, we implement this by adding an interaction term with a dummy variable for whether the firm has family members in non-managing positions. ${ }^{30}$ The estimated effects confirm that management is the driving force behind productivity increases as we do not find significant effects for firms with family members in non-managing positions. In columns (3) and (4) we replace the family firm dummy variables with the number of family members in managing and non-managing positions to exploit the full variation that we have in the data. ${ }^{31}$ Our findings are unchanged: Again, productivity increases are driven specifically by family management.

Family ownership. Family-managed firms are owned by families and family ownership has been shown to affect the governance of firms in various ways (e.g., Suáre and SantanaMartín 2004; Kim and Lu 2011), generating different incentives for undertaking innovation (e.g., differential tax incentives, different types of assets, different political connections, or different time horizon of running the business). In column (1) of Table 6, we test whether family management rather than family ownership is driving our results by restricting the sample to family-owned firms. Unfortunately the information on family ownership is only available at the very end of our sample, in 2006. We therefore need to assume that family ownership is unchanged over time and use the value in 2006 to identify family owned firms. When we restrict the sample to family owned firms, the marginal effects compare family owned and family-managed firms to family owned but professionally managed firms. The marginal effects in column (2) reveal that import competition increases the productivity of family-managed, family owned firms by more than those of professionally managed, but family owned firms, confirming our hypotheses that family management rather than other aspects of family firms are driving our results. Given that the ownership variable is available only at the end of the period, this is admittedly a rough test. However, it is the best we can do using the data in hand and nevertheless reassuring that our results hold.

Switch towards professional managers. As a final step we want to make sure that productivity improvements are not only driven by firms that replace their family managers by professional managers. Column (3) of Table 6 checks whether the observed productivity

\footnotetext{
${ }^{30}$ Note that, while having family managers in managing and non-managing positions is positively correlated, the correlation between the dummy variables is only 0.37 as we have firms in the sample that have family members in managing but not non-managing positions and vice versa.

${ }^{31}$ The number of family members in non-managing positions ranges between 1 and 6 . See the online appendix for a histogram and more details.
} 
improvements are driven by firms that replaced their family managers by professional managers. In order to do this, we exclude firms that are initially family-managed but switch to professional management at some point in the sample. It is reassuring to see that the results are not driven by those switchers. If anything, our findings seem to become stronger in magnitude. In a similar spirit, we check directly whether family management changes as a response to import competition in column (4) by using the change in the time-varying family firm dummy variable as a dependent variable. While the marginal differential effects reveal a small positive effect for initially unproductive firms, the effect is insignificantly different from zero. ${ }^{32}$ Overall, switches between family and non-family management cannot be used to rationalize our empirical findings.

\subsection{Robustness check: import competition}

While a reduction in tariffs increases import competition, this is not the only trade-related channel through which domestic firms are affected (Shu and Steinwender, 2019). First, reduced tariffs also have positive effects on domestic firms as they can import intermediate inputs more cheaply. Second, trade negotiations are often bilateral, resulting in two economies reducing the tariffs on each other, possibly for the same products. This results in another positive effect on firms as they obtain better access to the foreign market by exporting. In what follows, we test whether our regressions are indeed capturing the effect of increased import competition as opposed to better access to imported inputs or export markets.

Imported inputs. Access to inputs has been shown to increase productivity (e.g., Amiti and Konings, 2007; Topalova and Khandelwal, 2011). The productivity increase may be driven by lower prices or higher quality of imported inputs, or different inputs may allow for a more efficient arrangement of the production process. The first channel, increased productivity via lower input prices, is unlikely to show up in our estimates as our productivity changes are already purged of changes in input prices (see discussion in the data section). Furthermore, for these effects to show up in our estimates, they must be larger for initially unproductive firms - the limited empirical evidence on these heterogeneous effects however suggests the opposite (Iacovone, 2012). Nonetheless we can directly control for access to foreign inputs by including the change in input tariffs $I N T A R_{s t}$ (and its interaction terms

\footnotetext{
${ }^{32}$ The interpretation of the magnitude of the effects is as follows: An increase in import competition triggered by a $1 \mathrm{pp}$ tariff reduction leads to an increased likelihood of a firm changing management type by $1.7 \mathrm{pp}$ for the initially unproductive firms.
} 
with the initial productivity and initial status of family management) to our regression. Column (2) of Table E.15 in the online appendix conducts this exercise. The coefficients on input tariffs suggests that the effect of better access to intermediate inputs is positive for initially productive rather than unproductive firms but it is not statistically different between family and non-family firms. More importantly, it barely changes the effect of import competition: The effect is still positive for unproductive family relative to non-family firms. ${ }^{33}$ Notice that import and input tariffs are highly correlated at the industry level (0.81). However, as can be seen in Figure 1, there is variation in the year in which industries experience tariff changes, and in the magnitude of these changes. The correlation between changes in import tariffs and input tariffs is 0.22 , making it possible to identify their effects separately in the regression.

Export opportunities. The literature has also shown that better access to export markets leads to productivity increases (e.g., Lileeva and Trefler, 2010; Bustos, 2011; Iacovone, 2012; Mayer et al., 2016; Munch and Schaur, 2018). However, whether more or less productive firms are affected is less clear. Existing papers suggest that the positive effect is the largest at the lower (Lileeva and Trefler, 2010; Munch and Schaur, 2018), the middle (Bustos, 2011) or the upper end of the productivity distribution (Iacovone, 2012). In addition, there is no evidence that this affects family firms differently from non-family firms. In order to directly test this explanation, we control for the full interactions with "export tariffs," i.e., tariffs other countries impose on exports originating from the EU, EXPTAR $R_{s t}$. In column (3) of Table E.15 in the online appendix, we see that better access to export markets, i.e., through a reduction in export tariffs, leads to productivity increases in initially less productive firms. But this effect is not statistically different between family and non-family firms. Importantly, this exercise does not eliminate the differential effect of import competition on family relative to non-family firms. ${ }^{34}$

\footnotetext{
${ }^{33}$ In Table E.16 in the online appendix we show additional evidence that better access to imported inputs does not confound our estimates: We check whether import competition leads unproductive family firms to start importing, increase their imports, start importing technology, or increase their imports of technology. We do not find significant effects of any.

${ }^{34}$ In Table E. 16 in the online appendix we show additional evidence that better access to export markets does not confound our estimates: We check whether import competition leads unproductive family firms to start exporting or increase their exports but we do not find significant effects of either.
} 


\section{Model}

In this section we present a model that rationalizes our main empirical findings: After a reduction in import tariffs, family-managed firms at the lower end of the productivity distribution respond by increasing productivity. In our model we suggest that this is due to the specific preferences of family managers. Specifically, they care about the survival of the family firm and do not want to let the firm go bankrupt. We model this by giving family managers additional utility when the family firm exists, which they lose when the family firm goes bankrupt. ${ }^{35}$

There is ample evidence in favor of this type of preferences in the literature on family firms. Family managers have been shown to obtain a wide range of personal benefits from running the firm (e.g., Hurst and Pugsley, 2011; Bandiera et al., 2014; Belenzon et al., 2014; Gomez-Mejia et al., 2007; Besley and Ghatak, 2005; Prendergast, 2008; Bertrand et al., 2008; Mullins and Schoar, 2016; Bertrand and Mullainathan, 2003). For example, there is emotional attachment to the firm; the family firm also might allow for an increased social status or even allow for personal identification. Family managers may enjoy being their own boss, having flexible work hours, using the firm resources for private purposes, or having the opportunity to use the firm to address family issues (e.g., finding a prestigious job for a low-ability offspring).

We start with a static partial equilibrium model with heterogeneous firms and endogenous productivity. The key element of the model is that we allow managers to have heterogeneous preferences with respect to non-monetary private benefits of running the firm.

\subsection{Setup}

Firm profits. We assume that each firm draws a random initial productivity $\phi$ upon entry. The initial productivity draw is fixed throughout the model and its cumulative density function (CDF) is assumed to be $G(\phi)$. Firm profits are positively related to the exogenous productivity draw. Managers can exert effort $\beta$ which increases ex post firm productivity endogenously.

\footnotetext{
${ }^{35}$ Note that the driving feature of our model revolves around the characteristics of the manager of the firm rather than the owner or a non-managing employee of the firm. Therefore, we abstract from theoretical explanations that are based on the latter (e.g. tax incentives, political connections, asset mixes, or investment horizons that differ for family owned vs non family owned firms).
} 
We model the firm's profits $\pi$ in the following stylized way:

$$
\pi=(\eta+\phi \beta)-f
$$

The first term, $\eta$, is an exogenous market environment parameter that leads to decreased profits when import competition increases. We label the second term realized productivity, $\phi \beta$, of the firm which is a positive function of the initial productivity draw and managerial effort. We assume that there is a complementarity between exerting effort and the initial productivity draw, meaning that the marginal return to exerting effort increases with the initial draw. We label these two terms together variable or operating profits, $\eta+\phi \beta$.

Finally, the third term in the profit function is a fixed cost of production $f$ which the firm incurs in order to produce. If the variable profits are not enough to cover the fixed cost, the firm exits - the model therefore allows for endogenous exits. Furthermore, the manager can also let the firm exit and obtain zero utility without exerting any effort (i.e., the manager's outside option yields zero utility). However, if total profits (i.e., variable profits minus the fixed cost) are negative after the effort is exerted, the firm is forced to exit even if the manager would like to continue operating the firm, as our model is a static model. In this case, the manager obtains zero monetary income but still has to bear the disutility of exerting effort. In short, exit is not chosen by the owner or the manager once the manager has exerted effort. $^{36}$

Utility functions. The manager derives utility from both firm profits and non-monetary private benefits, which exist only when the firm exists. As we have argued above, we assume that $F$-type managers derive more of these private benefits than $P$-type managers. For simplicity, in what follows we assume that only $F$-type managers derive the non-monetary private benefits. However, the empirical predictions of the model are unchanged even if we allow for a private benefit of $P$-type managers, as long as it is small enough (and smaller than that of $F$-type managers). ${ }^{37}$ The utility of the manager also includes a private, convex cost of exerting effort, which is assumed to be the same for both type of managers.

\footnotetext{
${ }^{36}$ We implicitly assume that the firm cannot borrow and the manager cannot use his or her own wealth to cover the firm's losses in order to prevent the firm from exiting. This is true in our model, as the model is static. In addition, this seems to be a reasonable assumption as firms that go bankrupt probably face severe financial constraints and managers of those firms are likely also facing personal financial constraints.

${ }^{37}$ For more details on this, see our discussion after Proposition 3.
} 
Overall, the utility of $F$-type managers is given by:

$$
U_{F}= \begin{cases}(\eta+\phi \beta)-f-\frac{1}{2} \beta^{2}+\bar{U} & \text { if firm exists } \\ 0 & \text { if firm exits }\end{cases}
$$

where $\frac{1}{2} \beta^{2}$ is the effort cost and $\bar{U}$ represents the non-monetary private benefits.

The utility function of $P$-type managers differs from that of $F$-type managers only by the lack of the non-monetary private benefits:

$$
U_{P}= \begin{cases}(\eta+\phi \beta)-f-\frac{1}{2} \beta^{2} & \text { if firm exists } \\ 0 & \text { if firm exits }\end{cases}
$$

In the current model, we are silent on the utility function of owners; whether it differs across ownership types; and which contracts can be implemented. Instead, in the model, if a firm is family owned but professionally managed, its manager's objective function is the same as the one of the manager of a non-family owned (and thus professionally managed) firm. In this way, the model has the same predictions for all professional managers no matter whether they are family owned or not family owned. ${ }^{38}$

\subsection{Effort choice and realized productivity}

In this subsection we derive the optimal effort choice of both managers. The following proposition summarizes our result.

Proposition 1 (Optimal effort choice). Assume $f \geq \eta$ and $\bar{U}>\frac{f-\eta}{2},{ }^{39}$ then:

\footnotetext{
${ }^{38} \mathrm{We}$ could add owner preferences in a variety of ways and model predictions would still be unchanged. For example, one could assume that the family owner of a family owned but professionally managed firm only cares about firm profits. This makes sense, as several examples of the non-monetary benefit mentioned in the paper (e.g., the ability to use the firm's resources for personal purposes or to provide jobs for the manager's relatives) may more easily accrue to the manager rather than the owner. If this is the case, the family owner of a family owned but professionally managed firm is indifferent between exiting and receiving zero-profits. As a result, family owned but professionally managed firms would behave in the same way as non-family firms.

${ }^{39}$ The first assumption is a technical assumption, which is needed to generate endogenous exits. Otherwise, managers with any productivity draw can make their firms survive and obtain positive payoffs by choosing zero effort. The second assumption states that the private benefits are big enough such that even when the firm's final profits are zero (under the effort level that ignores the private benefits), $F$-type managers still have incentives to keep their firms alive by exerting more effort. Without the second assumption, the model would not generate a positive productivity response from initially unproductive family firms under tougher import competition, which is the purpose of the model.
} 
1. The optimal effort choice for a P-type manager is given by:

$$
\beta_{P}(\phi)=\phi \quad \text { if } \phi \geq \sqrt{2(f-\eta)} \equiv \underline{\phi}_{P}
$$

P-type managers with productivity draws below $\underline{\phi}_{P}$ exit the market.

2. The effort function of the P-type manager is increasing in $\phi$.

3. The optimal effort choice for a F-type manager is given by:

$$
\beta_{F}(\phi)= \begin{cases}\phi & \text { if } \phi \geq \sqrt{(f-\eta)} \equiv \bar{\phi}_{F} \\ \frac{f-\eta}{\phi} & \text { if } \phi \in\left[\frac{f-\eta}{\sqrt{2 \bar{U}}} \equiv \underline{\phi}_{F}, \bar{\phi}_{F}\right)\end{cases}
$$

$F$-type managers with productivity draws below $\underline{\phi}_{F}$ exit the market.

4. The effort function of the F-type manager is initially decreasing in $\phi$ and later increasing in $\phi$ (i.e., the relationship is " $U$-shaped").

Proof. In appendix.

Figure 4 illustrates the optimal effort as a function of initial productivity draw for $P$ type managers and for $F$-type managers. If productivity is high, i.e., above $\underline{\phi}_{P}$, both $F$-type and $P$-type managers behave in the same way. For both type of managers, effort increases in the initial productivity draw, because the two are complements. However, when initial productivity is below $\phi_{P}, P$-type managers let the firm exit, while $F$-type managers prefer to keep the firm alive in order to reap the private benefits. This creates an incentive for $F$-type manager to work harder and this incentive is larger the lower the initial productivity. If the initial productivity is too low, i.e., below even $\underline{\phi}_{F}$, ensuring firm survival requires too much effort and the $F$-type manager prefers to exit. Overall, the exit cutoff is lower for $F$-type managers than for $P$-type managers.

The kink in the effort function of $F$-type managers at $\bar{\phi}_{F}$ in Figure 4 also illustrates that there are two different ways in which the $F$-type manager is incentivized to exert effort. Below the kink, when the effort function is decreasing, the $F$-type manager exerts effort in order to make their firms break even and stay in the market. For further exposition, we label managers with initial productivity in this region the constrained managers. Above the kink, 
when the effort function is increasing, she exerts effort in order to increase the marginal profitability of the firm. We label these managers the unconstrained managers.

In addition to the predictions for effort choices, the model also has the following implications for productivity:

Proposition 2 (Realized productivity). Assume $f \geq \eta$ and $\bar{U}>\frac{f-\eta}{2}$, then:

1. Realized productivity of firms with P-type managers, $\beta_{P}(\phi) \phi$, increases in $\phi$ when $\phi \geq \phi_{P}$

2. Realized productivity of firms with F-type managers, $\beta_{F}(\phi) \phi$, is constant for $\phi \in$ $\left[\underline{\phi}_{F}, \bar{\phi}_{F}\right)$ and increasing in $\phi$ for $\phi \geq \bar{\phi}_{F}$.

3. Average realized productivity of firms with P-type managers is higher than that of firms with F-type managers.

4. Assume that the initial productivity draw follows the same Pareto distribution for both $F$-type firms and P-type firms. Then, the distribution of realized productivity of P-type firms first order stochastically dominates that of F-type firms.

Proof. See appendix.

Figure 5 illustrates how realized log productivity, which is a combination of the initial productivity draw and the optimally chosen effort, varies with the initial productivity draw for $P$-type managers and for $F$-type managers. Realized productivity weakly increases in the initial productivity for both type of managers but more importantly, as the exit cutoff for professional firms is larger, average observed productivity for $P$-type firms is higher than that of $F$-type firms.

\subsection{Impact of import competition on productivity}

In this subsection we analyze how stiffer import competition affects the realized productivity of $F$-type firms and $P$-type firms differentially. Specifically, we conduct a comparative statics exercise of a decrease in $\eta$ (i.e., an increase in import competition) on managerial effort and firm productivity. We use superscripts $B$ and $A$ to denote variables before and after a reduction in import tariffs. The following propositions state formally how tougher import competition affects $F$-type firms and $P$-type firms differently: 
Proposition 3 (Productivity change for F-type firms and P-type firms). Assume $f \geq \eta$ and $\bar{U}>\frac{f-\eta}{2}$. Suppose the market environment parameter decreases from $\eta^{B}$ to $\eta^{A}$, i.e., import competition increases. Then:

1. The realized productivity of each surviving P-type firm is not affected.

2. For surviving F-type firms, the initially least productive surviving firms increase their realized productivity, whereas the initially most productive surviving firms do not change their realized productivity.

3. For the initially most productive surviving firms, the induced productivity change of F-type and P-type firms is the same. For the initially least productive surviving firms, the productivity change for F-type firms is larger than that of P-type firms.

Proof. See appendix.

Figure 6 illustrates the change in the managerial effort and firm productivity graphically in response to an increase in import competition. The least productive surviving $F$-type firms increase productivity as stiffer import competition incentivizes their managers to exert more effort to ensure the survival of their firms (i.e., by just earning non-negative profits). On the contrary, the most productive surviving $F$-type firms and all $P$-type firms do not change their productivity, as their managers' effort does not depend on the market environment parameter. This is the main proposition of our simple, stylized model that can rationalize our empirical findings. ${ }^{40}$

In order to understand Figure 6 better, we discuss the behavior of $F$-type managers case by case. Consider Panel A, which illustrates the change in effort. First, when $\phi \in\left[\underline{\phi}_{F}^{A}, \bar{\phi}_{F}^{B}\right)$, $F$-type managers make their firms break even both before and after the import competition becomes stiffer. As a result, the effort level is $\frac{f-\eta^{B}}{\phi}$ before, and $\frac{f-\eta^{A}}{\phi}$ after. Therefore,

\footnotetext{
${ }^{40}$ Notice that positive shocks, such as improved access to export markets or imported inputs, would only lead to differential productivity effects between F-type and P-type firms in the model if the shocks affected the exit cutoff, i.e., if the shocks affected the profits of unproductive firms. According to the literature, improved access to export markets or imported inputs are unlikely to affect unproductive firms in the short run (i.e., without GE effects). For example, the Melitz (2003) model shows how only productive firms can cover the fixed cost of exporting and thus benefit from export opportunities, and empirical studies have confirmed this pattern (e.g., Lileeva and Trefler 2010; Bustos 2011; Iacovone et al. 2011). Similarly, empirical evidence suggests that more productive firms are more likely to benefit from access to intermediate inputs (Iacovone, 2012). Table E.15 in the online appendix is consistent with these findings from the literature, as we find no differential effects for family- and non-family firms from input or export tariffs.
} 
the difference in effort equals $\frac{\eta^{B}-\eta^{A}}{\phi}$, which decreases in $\phi$. This explains the convexly decreasing part of the effort change for family managers. Next, when $\phi \in\left[\bar{\phi}_{F}^{B}, \bar{\phi}_{F}^{A}\right), F$-type managers make their firms earn positive profits before the import shock but zero profit after the import shock. As a result, the effort level is $\phi$ before the import shock and $\frac{f-\eta^{A}}{\phi}$ after the import shock. Therefore, the difference in effort decreases in $\phi$. Finally, when $\phi \geq \bar{\phi}_{F}^{A}$, $F$-type managers make their firms earn positive profits both before and after. As a result, their effort level is $\phi$ both before and after, and the difference is therefore zero.

Now consider Panel B, which illustrates the change in $\log$ productivity. When $\phi \in$ $\left[\phi_{F}^{A}, \bar{\phi}_{F}^{B}\right)$, the logarithm of productivity is $\ln \left(f-\eta^{B}\right)$ before and $\ln \left(f-\eta^{A}\right)$ after the shock. The change in the logarithm of productivity equals $\ln \left(f-\eta^{B}\right)-\ln \left(f-\eta^{A}\right)$ which is constant as it does not vary with $\phi$. When $\phi \in\left[\bar{\phi}_{F}^{B}, \bar{\phi}_{F}^{A}\right)$, the logarithm of productivity is $\phi^{2}$ before and $f-\eta^{A}$ after the import shock. Therefore, the change in the logarithm of productivity decrease with $\phi$. Finally, when $\phi \geq \bar{\phi}_{F}^{A}$, there is no change in effort and thus no change in productivity.

Overall, changes in the effort and the logarithm of productivity both decrease with the initial productivity draw $\phi$ for $F$-type managers under tougher import competition.

It is worth noting that the empirical predictions of the above proposition do not depend on the assumption that $P$-type managers receive no private benefits by running the firms. In fact, as long as the private benefits $P$-type managers receive are smaller than $\frac{f-\eta}{2}$ (i.e., $\bar{U} \leq \frac{f-\eta}{2}$, which is opposite the assumption made for the private benefits of $F$-type managers), the effort choice is still $\phi$ for all $P$-type managers, which does not respond to a change in the market environment parameter $\eta$. As a result, their effort and their firms' productivity do not change after import competition increases. In short, our results hold as long as the private benefits of $F$-type managers are above - and the benefits of $P$-type managers are below a certain threshold.

In Figure 6, there are no $P$-type firms that have the same productivity draws as $F$-type firms that increase effort and productivity under tougher import competition. However, this is merely a special feature of our simplified model in which both $F$-type and $P$-type firms have the same fixed cost, $f$. When we allow the fixed cost to differ between $F$-type and $P$-type firms as in Figure 7, the model can generate an overlap of the productivity draws between these $P$-type and $F$-type firms.

Although (a fraction of) $F$-type firms increase productivity and not a single $P$-type firm 
increases productivity when import competition becomes stiffer, it is actually possible for the gains in aggregate productivity to be lower among $F$-type firms than among $P$-type firms. To see this, notice that gains in aggregate productivity arise through two channels: endogenous productivity increases of existing firms (the within-firm channel) and reallocation across firms (the between-firm channel). In a world with only $F$-type firms, productivity improvements in unproductive firms hinders the resource reallocation toward productive firms. In contrast, in a world with only $P$-type firms, unproductive firms exit (instead of improving their productivity), which facilitates resource reallocation toward productive firms. Aggregate productivity gains therefore depend on whether the between-firm channel of resource reallocation dominates the within-firm productivity gains, and a quantitative general equilibrium model would be needed to answer this question, which is outside the scope of this paper.

Proposition 4 (Exits and profits). Assume $f \geq \eta$ and $\bar{U}>\frac{f-\eta}{2}$. Suppose the market environment parameter decreases from $\eta_{1}$ to $\eta_{2}$, i.e., import competition increases. Then:

1. The exit cutoff on realized log productivity increases for both F-type firms and P-type firms. As a result, the least productive firms of either type exit.

2. For firms with the same realized initial productivity, P-type firms are more likely to exit than F-type firms.

3. Profits of all P-type firms decrease. Profits of the initially most productive F-type firms decrease, while the initially least productive F-type firms have their profits unchanged. As a result, among the initially least productive surviving firms, profits of F-type firms fall less than profits of P-type firms.

Proof. See appendix.

\section{Additional empirical evidence}

The objective of the model was to provide a rationale for explaining our main results in the data: Initially unproductive family firms increase their productivity in response to an import competition shock, while we see no significant changes for initially productive family firms 
or non-family firms (Table 3). Proposition 3 qualitatively predicts this pattern. ${ }^{41}$ However, ours may not be the only model that can rationalize the empirical findings. We therefore explore in this section how likely it is that the mechanism proposed in the model is the correct one, and whether additional predictions of the model are consistent with the data.

Innovation. We start by investigating what kind of activities managers undertake in response to import competition. In column (2) of Table 7 we check whether firms that respond to import competition also start to perform $R \& D$ activities, using the change in the $R \& D$ dummy variable as a dependent variable. However, we cannot find significant marginal effects. In column (3) we use the change in the R\&D expenses that a firm reports as a dependent variable. ${ }^{42}$ Family firms at both ends of the productivity distribution report increased spending relative to non-family firms, but the estimated effects are not significant. In column (4) we check whether the firm reports a change in the number of patents. We estimate positive effects for initially unproductive family firms relative to non-family firms, but the effects are again insignificant. ${ }^{43}$

Overall, we do not see a differential increase in innovation related activities in response to import competition. This is consistent with the mechanism in the model. R\&D and patenting are innovation activities that span a longer time horizon, and are therefore not suitable to increase cash flow to ensure survival. Furthermore, firms that are faced with increased bankruptcy risk due to tougher import competition probably do not have the resources in order to invest into R\&D.

Efficiency. In Table 8 we conduct another exercise to shed light on what is going on inside the firm by regressing the different components of labor productivity separately on import competition and the respective interaction terms. Comparing columns (2), deflated value added, with column (5), employment, we see that increases in value added rather

\footnotetext{
${ }^{41}$ Note that strictly speaking, the model predicts a sharp non-linear effect of import competition on the productivity of family firms, whereas our data suggests a more linear effect. Measurement error in productivity or uncertainty with respect to how effort translates into productivity could smooth the strict prediction of the model.

${ }^{42}$ Note that we can only do this for firms that report positive R\&D expenses, which explains why the sample size drops significantly.

${ }^{43} \mathrm{We}$ also checked whether product or process innovation changed, but did not find significant effects. Notice that the effects on productivity in column (1) are robust to restricting the sample to the ones used in columns (2) to (4).
} 
than reductions in employment drive the productivity increase. ${ }^{44}$ Decomposing value added into sales in column (3) and material in column (4) makes clear that initially unproductive family firms increase their labor productivity by reducing their material inputs (rather than increasing their sales). We also show in column (6) that productivity improvements are not driven by increases in the capital stock. ${ }^{45}$

This is again evidence in support of the mechanism in the model, as it suggests that firms are trying to use their materials more efficiently in order to increase their short-term cash flow and their survival probability. Managers may be able to improve material efficiency in a variety of ways: They may source the buying inputs at lower prices, they may run down the material inventories, or they may use the same material inputs more efficiently in production. Either interpretation is consistent with the mechanism in the model, in which managers are trying to ensure survival into the next period. But we can dig a little bit deeper.

First, we know that the decrease in material usage is not driven by using cheaper materials, as we already deflated material expenditure by change in material prices. ${ }^{46}$ This also implies that we do not purely see reduced tunneling of profits to suppliers when import competition increases (Bertrand, Mehta, and Mullainathan, 2002).

Second, if the effects were driven by a run-down in inventory, they would have to be restocked in the next period. As a result, we would see an equivalent productivity decrease in the following period. However, when we run our regressions on changes over two years, we still find significant positive effects of import competition on the productivity of initially unproductive family firms (results in Table E.18 of the online appendix). The most likely explanation for our findings is therefore that managers are using the same material inputs more efficiently in the production process to generate more output.

Reducing waste in material usage and inventory is an integral part of lean manufacturing (e.g., a part of the so called "5 S" workplace organization method), a method often used by companies trying to increase profitability in the face of increased competition. While lean approaches require effort on the part of managers and employees to identify waste,

\footnotetext{
${ }^{44}$ This is maybe not surprising as the Spanish labor market has been characterized as very rigid. In Table E.17 in the online appendix we also check whether the workers supplied by a temporary agency or total employment of family members changed, but we did not find significant effects.

${ }^{45}$ This is consistent with our results in Table E.12 of the online appendix, in which we show that the productivity increases are also reflected in TFP increases.

${ }^{46} \mathrm{We}$ also checked whether import competition affected input prices, but there are no significant effects.
} 
the changes can be implemented relatively quickly and improve the cash flow position of a company (Liker and Meier, 2005). ${ }^{47}$

Overall, these results are consistent with managers putting more effort towards increasing efficiency (by reducing material usage and eliminating waste) rather than innovation (by increasing $\mathrm{R} \& \mathrm{D}$ or patenting). The former can help to increase efficiency, improve cash flows and therefore avoid immediate bankruptcy, whereas the latter improves long-run success, but is more risky if the firm does not survive. This is consistent with the mechanism in the model, which is triggered by the motive to keep the firm alive another day.

Multi-generational family firms. The model assumes that family managers care more about the survival of the firm than professional managers, in line with the findings in the literature on family firms. In Table 9 we test this assumption directly by checking whether our results are stronger for those family managers whom we suspect to be especially motivated to keep the family firm alive in the long run: multi-generational firms, which we measure by the number of family managers present. While we do not have an exact measure of the number of generations, we think that these firms correspond closest to a multi-generational family firm. Column (1) repeats the result for non-family firms, and in columns (2) and (3) we split the sample of family firms into those that have one family manager versus those that have more than one family manager. The effect for initially unproductive firms is larger for the latter. Columns (4) to (6) repeat the same regressions with firm fixed effects, we see a very similar pattern.

Cross-sectional productivity differences. The model has additional predictions that we can check in the data. First, while we are interested in explaining productivity changes, the model yields predictions concerning differences in the productivity distribution of family versus non-family firms in the cross section. Most noticeable, Proposition 2 explains that family firms are, on average, less productive than non-family firms. This is a frequent finding of the literature and also supported in our data, as Table 1 shows. The literature usually rationalizes this finding using assumptions of worse abilities or lower willingness to work of

\footnotetext{
${ }^{47}$ Lean management techniques can not only deliver one-time productivity boosts, but the underlying principle is "a philosophy of continuous improvement", as e.g. the Office of Continuous Improvement (OCI) at Michigan Tech describes it (https://www.mtu.edu/improvement/learn/what/). It is therefore possible for firms to repeatedly increase efficiency over our time period of 14 years, if they are hit by several shocks. Since we estimate the average response of firms, it is possible that efficiency improvements are larger than our estimates the first time a firm is hit, and smaller as firms experience additional shocks. However, notice that large tariff reductions happen at most two to three times per industry during our sample period.
} 
family managers (e.g., Bertrand and Schoar, 2006; Bandiera et al., 2014; Bloom, Genakos, Sadun, and Van Reenen, 2012). In our model, however, family managers have the same initial abilities as non-family managers on average, since the distribution of the productivity draws is the same for both types of firms. Also, they exert either the same level of effort or even more: They keep putting in effort for initially unproductive firms that professional managers would have let go bankrupt. Yet, precisely because of the desire to keep unproductive family firms alive, the model results in lower (average) realized productivity for family firms.

Proposition 2 also predicts that the distribution of realized productivities of non-family firms first-order stochastically dominates that of family firms. Figure 8 plots the empirical CDF of the log labor productivity for both types of firms. The figure shows that this prediction indeed holds in the data.

Exits. Another prediction from the model is Proposition 4, which states that import competition leads to exits of non-productive firms of either type. In Table E.19 in the online appendix we see that import competition indeed leads to exits. ${ }^{48}$ Overall, a fall in import tariffs by $1 \mathrm{pp}$ increases the average probability of exit by $0.2 \mathrm{pp}$. In Figure 9 we run nonparametric regressions of import competition on exits by tercile in the initial productivity distribution, separately for family and non-family firms. ${ }^{49}$ The exit probability is indeed largest for unproductive non-family firms, as our proposition suggests, and statistically different from zero. ${ }^{50}$ The magnitude implies that for these firms, an increase in import tariffs by 1 percentage point implies an increase in the exit probability by 0.6 percentage points. One note of caution: While this is supportive evidence of the mechanism described in the model, the standard errors are too large to conclude that the exit probabilities are statistically different from the exit probabilities of family-firms for the lowest tercile. ${ }^{51}$

Profits. Proposition 4 also predicts that less productive family-firms experience a smaller

\footnotetext{
${ }^{48}$ Exiting firms include closed firms, firms in liquidation, and firms that are taken over by other firms.

${ }^{49}$ Given that the effect of import competition is predicted to be non-linear in initial productivity, i.e., much more pronounced for initially unproductive firms, this specification is more consistent with the data and model than the linear interaction terms that we use for other outcomes.

${ }^{50}$ As robustness check, in Figure D.8 of the online appendix we repeat this exercise, moving the exit year forward when firms report non-response in the years before the actual exit year. This does not affect the results.

${ }^{51}$ The difference between family and non-family firms in the lowest tercile is $-0.50(0.49)$, with a p-value of 0.305 .
} 
decline in profits relative to less productive non-family firms, as their managers exert more effort in order to avoid bankruptcy. In line with this prediction, we have already shown in column (2) of Table 8 that less productive family firms experience increases in value added relative to non-family firms, while this difference is insignificant for productive firms. In column (7) of Table 8 we see this pattern also reflected in gross profits (defined as value added minus gross labor cost), confirming that the reductions in material cost are not offset by increases in labor cost, and that these firms indeed experience differentially larger gross profits.

\section{Conclusion}

Our results shed light on the behavior of family firms, which contribute to a large share of economic activities in many countries throughout the world. Economists have long been worried about the implications of unsatisfactory performance of family firms on welfare and aggregate productivity. The surge of China's exports in recent decades has increased the bankruptcy risk of these firms. Our findings suggest that the attachment of family managers to their firms creates a stronger motive to "fight" against bankruptcy when the import shock hits. This mechanism may help to reconcile the mixed evidence of import competition on productivity in existing empirical studies, which have found positive effects for emerging economies that typically host a large number of family managers.

The positive effect of import competition on productivity is in contrast to the literature that has pictured family managers as less able or less productive. However, all is not well: The increased effort is targeted towards improving short-term efficiency (to ensure survival) rather than long-term productivity based on innovation or research and development. Future research should focus on embedding these findings into a general equilibrium trade model that can help us understand how the difference in managers' preferences affects gains in aggregate productivity and welfare after trade liberalization. 


\section{References}

Ahn, J., H. Han, and Y. Huang (2018). Trade with Benefits: New Insights on Competition and Innovation. Economics Section, The Graduate Institute of International Studies No. 07-2018.

Amiti, M. and J. Konings (2007). Trade liberalization, intermediate inputs, and productivity: Evidence from indonesia. American Economic Review, 1611-1638.

Anderson, R. C. and D. M. Reeb (2003). Founding-family ownership and firm performance: evidence from the S\&P 500. The Journal of Finance 58(3), 1301-1328.

Autor, D., D. Dorn, G. H. Hanson, G. Pisano, and P. Shu (2017, December). Foreign Competition and Domestic Innovation: Evidence from U.S. Patents. NBER Working Paper No. 22879.

Autor, D. H., D. Dorn, and G. H. Hanson (2013, October). The China Syndrome: Local labor market effects of import competition in the United States. American Economic Review 103(6), 2121-68.

Bandiera, O., L. Guiso, A. Prat, and R. Sadun (2011). What do CEOs do? Technical report, Harvard Business School Working Paper.

Bandiera, O., L. Guiso, A. Prat, and R. Sadun (2014). Matching firms, managers, and incentives. Journal of Labor Economics.

Bandiera, O., A. Prat, and R. Sadun (2014). Managing the family firm: Evidence from CEOs at work. Technical report, Harvard Business School Working Paper.

Belenzon, S., A. K. Chatterji, and B. Daley (2014). Eponymous entrepreneurs. Working paper.

Bennedsen, M., K. M. Nielsen, F. Perez-Gonzalez, and D. Wolfenzon (2007). Inside the family firm: The role of families in succession decisions and performance. The Quarterly Journal of Economics 122(2), 647-691.

Berger, H. and V. Nitsch (2008). Zooming out: The trade effect of the euro in historical perspective. Journal of International Money and Finance 27(8), 1244 - 1260.

Bergin, P. R. and C.-Y. Lin (2012). The dynamic effects of a currency union on trade. Journal of International Economics 87(2), 191 - 204.

Bertrand, M., S. Johnson, K. Samphantharak, and A. Schoar (2008). Mixing family with business: A study of Thai business groups and the families behind them. Journal of Financial Economics 88(3), 466-498.

Bertrand, M., P. Mehta, and S. Mullainathan (2002). Ferreting out tunneling: An application to Indian business groups. The Quarterly Journal of Economics 117(1), 121-148.

Bertrand, M. and S. Mullainathan (2003). Enjoying the quiet life? corporate governance and managerial preferences. Journal of Political Economy 111(5), 1043-1075.

Bertrand, M. and A. Schoar (2006, June). The role of family in family firms. Journal of Economic Perspectives 20(2), 73-96.

Besley, T. and M. Ghatak (2005). Competition and incentives with motivated agents. American Economic Review 95(3), 616-636.

Beveren, I. V. (2012, 02). Total factor productivity estimation: A practical review. Journal of Economic Surveys 26(1), 98-128. 
Bloom, N., M. Draca, and J. Van Reenen (2016). Trade induced technical change? the impact of chinese imports on innovation, it, and productivity. The Review of Economic Studies 83(1), 87 - 117.

Bloom, N., B. Eifert, A. Mahajan, D. McKenzie, and J. Roberts (2013). Does management matter? evidence from India. The Quarterly Journal of Economics 128(1), 1-51.

Bloom, N., C. Genakos, R. Sadun, and J. Van Reenen (2012). Management practices across firms and countries. Academy of Management Perspectives 26(1), 12-33.

Bloom, N., K. Manova, J. Van Reenen, S. T. Sun, and Z. Yu (2018). Managing trade: evidence from China and the US. Technical report, National Bureau of Economic Research.

Bloom, N. and J. Van Reenen (2007). Measuring and explaining management practices across firms and countries. The Quarterly Journal of Economics 122(4), 1351-1408.

Bloom, N. and J. Van Reenen (2010). Why do management practices differ across firms and countries? Journal of Economic Perspectives 24(1), 203-24.

Bombardini, M., B. Li, and R. Wang (2017). Import Competition and Innovation: Evidence from China. Working Paper.

Brandt, L., J. Van Biesebroeck, L. Wang, and Y. Zhang (2017, September). WTO Accession and Performance of Chinese Manufacturing Firms. The American Economic Review 107(9), 2784-2820.

Brouwer, J., R. Paap, and J.-M. Viaene (2008). The trade and FDI effects of EMU enlargement. Journal of International Money and Finance 27(2), 188 - 208. Euro Area Expansion: Current State and Future Prospects.

Burkart, M., F. Panunzi, and A. Shleifer (2003). Family firms. The Journal of Finance 58(5), 2167-2202.

Bustos, P. (2011). Trade liberalization, exports, and technology upgrading: Evidence on the impact of MERCOSUR on Argentinian firms. American Economic Review 101(1), 304-340.

Caliendo, L. and E. Rossi-Hansberg (2012). The impact of trade on organization and productivity. The Quarterly Journal of Economics 127(3), 1393-1467.

Chakraborty, P. and O. Raveh (2018). Input-trade liberalization and the demand for managers: Evidence from India. Journal of International Economics 111, 159-176.

Coelli, F., A. Moxnes, and K. H. Ulltveit-Moe (2018). Better, Faster, Stronger: Global Innovation and Trade Liberalization. Technical report.

Dang, D. A. (2017). The effects of Chinese import penetration on firm innovation: Evidence from the Vietnamese manufacturing sector. WIDER Working Paper 2017/77.

De Loecker, J. (2007, September). Do exports generate higher productivity? Evidence from Slovenia. Journal of International Economics 73(1), 69-98.

De Loecker, J. (2011, 09). Product differentiation, multiproduct firms, and estimating the impact of trade liberalization on productivity. Econometrica 79(5), 1407-1451.

De Loecker, J. (2013). Detecting learning by exporting. American Economic Journal: Microeconomics 5(3), 1-21.

Demsetz, H. and K. Lehn (1985). The structure of corporate ownership: Causes and consequences. Journal of Political Economy, 1155-1177.

Fernandes, A. M. (2007). Trade policy, trade volumes and plant-level productivity in Colom- 
bian manufacturing industries. Journal of International Economics 71(1), 52 - 71.

Fernandes, A. M. and C. Paunov (2009). Does tougher import competition foster product quality upgrading? World Bank Policy Research Working Paper Series.

Fieler, A. C. and A. Harrison (2018, April). Escaping Import Competition and Downstream Tariffs. NBER Working Paper No. 24527.

Gallo, M. A. and C. G. Pont (1989). The family business in the Spanish economy. Working Paper 144, IESE Business School.

Gomez-Mejia, L. R., K. T. Haynes, M. Nunez-Nickel, K. J. L. Jacobson, and J. MoyanoFuentes (2007). Socioemotional wealth and business risks in family-controlled firms: Evidence from Spanish olive oil mills. Administrative Science Quarterly 52(1), 106-137.

Gorodnichenko, Y., J. Svejnar, and K. Terrell (2010). Globalization and innovation in emerging markets. American Economic Journal: Macroeconomics 2(2), 194-226.

Guadalupe, M., O. Kuzmina, and C. Thomas (2012, December). Innovation and foreign ownership. American Economic Review 102(7), 3594-3627.

Hart, O. D. (1983). The market mechanism as an incentive scheme. The Bell Journal of Economics, 366-382.

Hermalin, B. E. (1992). The effects of competition on executive behavior. The RAND Journal of Economics, 350-365.

Hombert, J. and A. Matray (2017). Can innovation help US manufacturing firms escape import competition from China? Working Paper.

Hurst, E. and B. W. Pugsley (2011). What do Small Businesses Do? Brookings Papers on Economic Activity 43(2 (Fall)), 73-142.

Iacovone, L. (2012). The better you are the stronger it makes you: Evidence on the asymmetric impact of liberalization. Journal of Development Economics 99(2), 474-485.

Iacovone, L., W. Keller, and F. Rauch (2011). Innovation Responses to Import Competition. Working Paper.

Instituto de la Empresa Familiar (2018). Factores de competitividad y análysis financiero en la empresa familiar. Technical report.

James, H. S. (1999). Owner as manager, extended horizons and the family firm. International Journal of the Economics of Business 6(1), 41-55.

Kim, E. H. and Y. Lu (2011). CEO ownership, external governance, and risk-taking. Journal of Financial Economics 102(2), 272-292.

KPMG (2017). VI Barómetro Empresa Familiar. Technical report.

Kueng, L., N. Li, and M.-J. Yang (2017). The Impact of Emerging Market Competition on Innovation and Business Strategy: Evidence from Canada. Working Paper.

Leibenstein, H. (1966). Allocative efficiency vs. 'x-efficiency'. The American Economic Review, 392-415.

Lemos, R., D. Scur, et al. (2016). All in the family? CEO succession and firm organization. Technical report, Centre for the Study of African Economies, University of Oxford.

Leuven, E. and B. Sianesi (2003, April). PSMATCH2: Stata module to perform full Mahalanobis and propensity score matching, common support graphing, and covariate imbalance testing. Statistical Software Components, Boston College Department of Economics. Liker, J. K. and D. Meier (2005). The Toyota Way Fieldbook. New York: McGraw-Hill. 
Lileeva, A. and D. Trefler (2010, August). Improved access to foreign markets raises plantlevel productivity... for some plants. The Quarterly Journal of Economics 125(3), 10511099.

Mayer, T., M. J. Melitz, and G. I. Ottaviano (2016). Product mix and firm productivity responses to trade competition. NBER Working Paper No. 22433.

Medina, P. (2018). Import Competition, Quality Upgrading and Exporting: Evidence from the Peruvian Apparel Industry. Working Paper.

Melitz, M. J. (2003, November). The impact of trade on intra-industry reallocations and aggregate industry productivity. Econometrica 71(6), 1695-1725.

Morck, R., A. Shleifer, and R. W. Vishny (1988). Management ownership and market valuation: An empirical analysis. Journal of Financial Economics 20, 293-315.

Morck, R. K., D. A. Stangeland, and B. Yeung (2000, January). Inherited wealth, corporate control, and economic growth: The Canadian Disease?, pp. 319-372. University of Chicago Press.

Muendler, M.-A. (2004). Trade, Technology and Productivity: a study of Brazilian Manufacturers 1986-1998. CESIFO Working Paper No. 1148.

Mullins, W. and A. Schoar (2016). How do CEOs see their roles? Management philosophies and styles in family and non-family firms. Journal of Financial Economics 119(1), 24 43.

Munch, J. and G. Schaur (2018, February). The Effect of Export Promotion on Firm-Level Performance. American Economic Journal: Economic Policy 10(1), 357-387.

Olley, G. S. and A. Pakes (1996). The dynamics of productivity in the telecommunications equipment industry. Econometrica 64(6), 1263-1297.

Ornaghi, C. (2006). Assessing the effects of measurement errors on the estimation of production functions. Journal of Applied Econometrics 21(6), 879-891.

Pavcnik, N. (2002). Trade liberalization, exit, and productivity improvements: Evidence from Chilean plants. The Review of Economic Studies 69(1), 245-276.

Pérez-González, F. (2006). Inherited control and firm performance. American Economic Review, 1559-1588.

Prendergast, C. (2008). Intrinsic motivation and incentives. American Economic Review 98(2), 201-05.

Raith, M. (2003). Competition, risk, and managerial incentives. American Economic Review 93(4), 1425-1436.

Schmidt, K. M. (1997). Managerial incentives and product market competition. The Review of Economic Studies 64(2), 191-213.

Schmitz Jr, J. A. (2005). What determines productivity? lessons from the dramatic recovery of the U.S. and Canadian iron ore industries following their early 1980s crisis. Journal of Political Economy 113(3), 582-625.

Schor, A. (2004). Heterogeneous productivity response to tariff reduction. evidence from Brazilian manufacturing firms. Journal of Development Economics 75(2), 373 - 396. 15 th Inter American Seminar on Economics.

Shleifer, A. and R. W. Vishny (1986). Large shareholders and corporate control. The Journal of Political Economy, 461-488. 
Shleifer, A. and R. W. Vishny (1997). A survey of corporate governance. The Journal of Finance.

Shu, P. and C. Steinwender (2019). The Impact of Trade Liberalization on Firm Productivity and Innovation, pp. 39-68. University of Chicago Press.

Stein, J. C. (1988). Takeover threats and managerial myopia. The Journal of Political Economy, 61-80.

Stein, J. C. (1989). Efficient capital markets, inefficient firms: A model of myopic corporate behavior. The Quarterly Journal of Economics, 655-669.

Suáre, K. and D. Santana-Martín (2004). Governance in Spanish family business. International Journal of Entrepreneurial Behavior \& Research 10(1/2), 141-163.

Topalova, P. and A. Khandelwal (2011). Trade Liberalization and Firm Productivity: The Case of India. The Review of Economics and Statistics 93(3), 995-1009.

Villalonga, B. and R. Amit (2006). How do family ownership, control, and management affect firm value? Journal of Financial Economics 80(2), 385-417.

Wooldridge, J. M. (2010). Econometric Analysis of Cross Section and Panel Data. Number 0262232588 in MIT Press Books. The MIT Press.

$\mathrm{Wu}, \mathrm{Y}$. (2011). Managerial incentives and compensation in a global market. CEP Discussion Paper No 1066.

$\mathrm{Xu}, \mathrm{R}$. and K. Gong (2017). Does Import Competition Induce R\&D Reallocation? Evidence from the US. International Monetary Fund. 
Figure 1: EU import tariffs over time

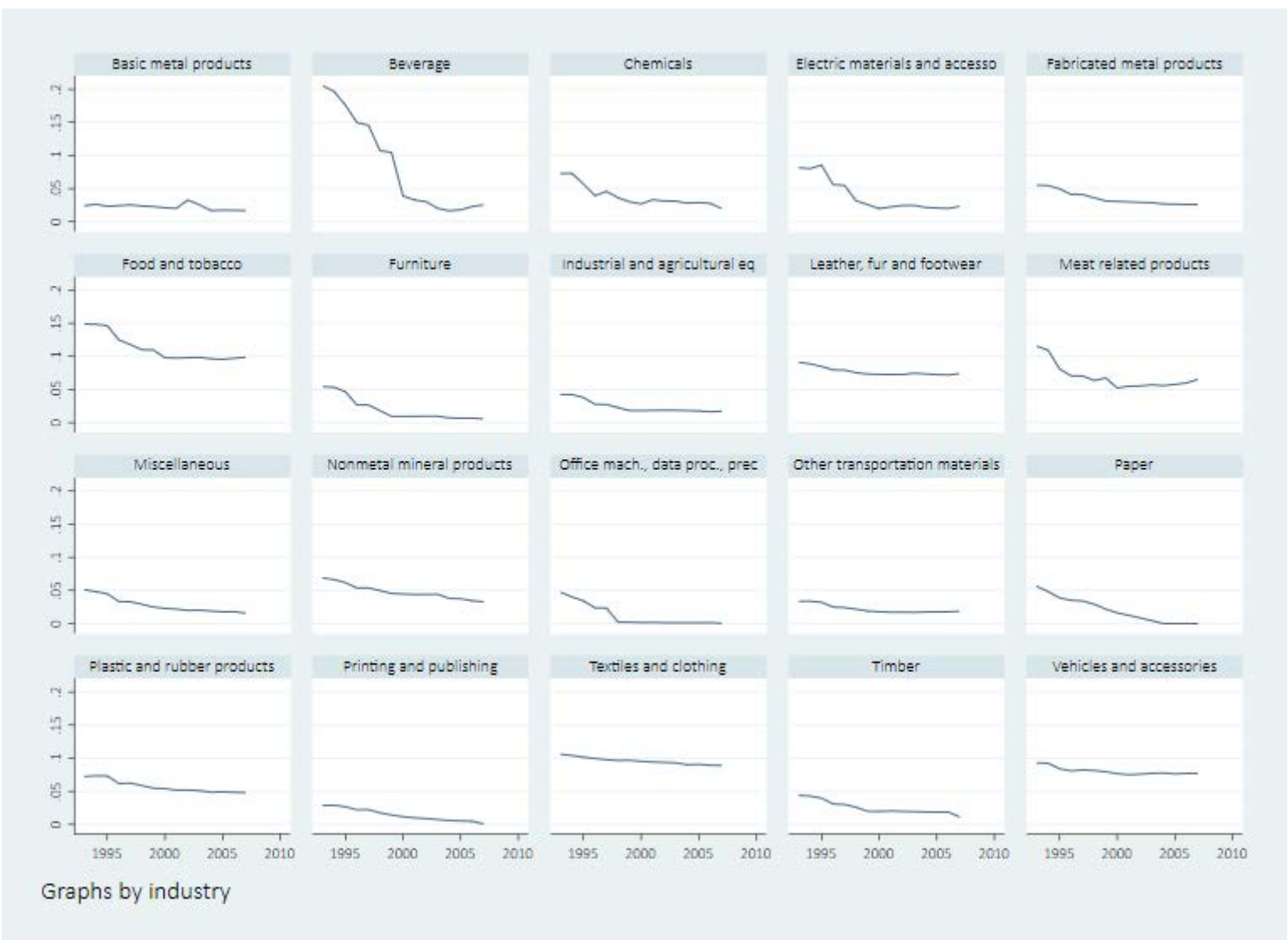

Source: TRAINS database (provided by UNCTAD), accessed by World Integrated Trade Solution (WITS), wits.worldbank.org

Figure 2: Effect of import competition on labor productivity: Non-parametric estimation
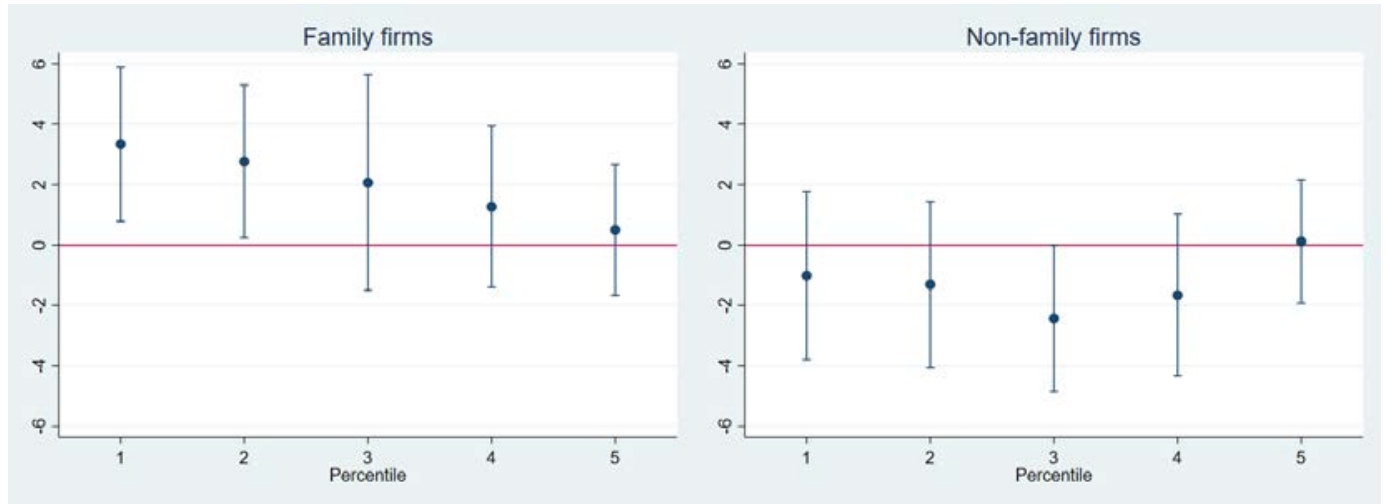
Figure 3: Effect of import competition
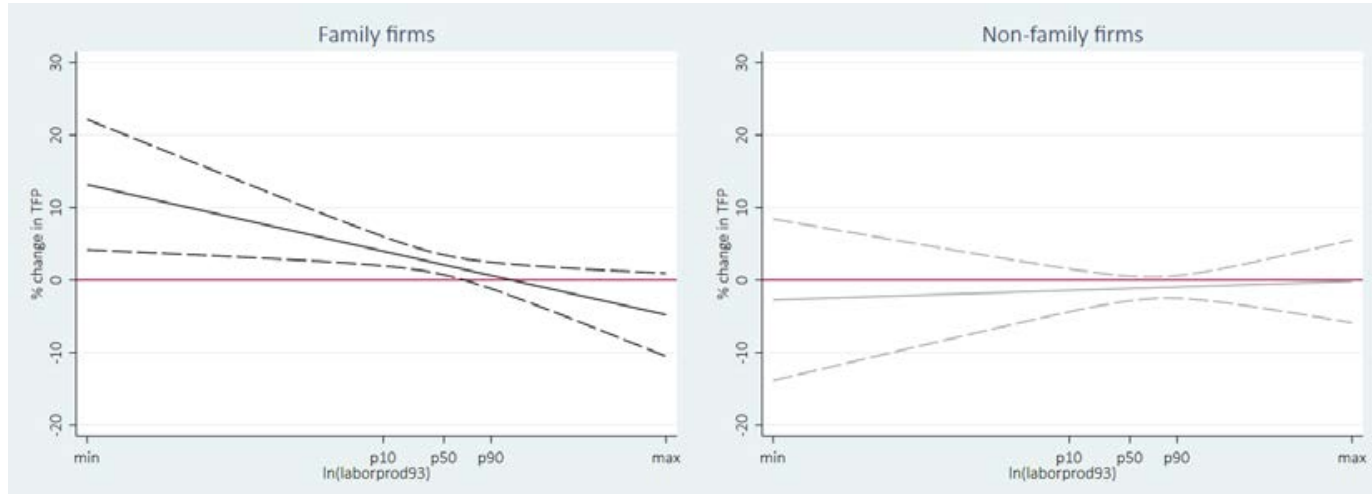

Figure 4: Effort choices of F-type and P-type firms

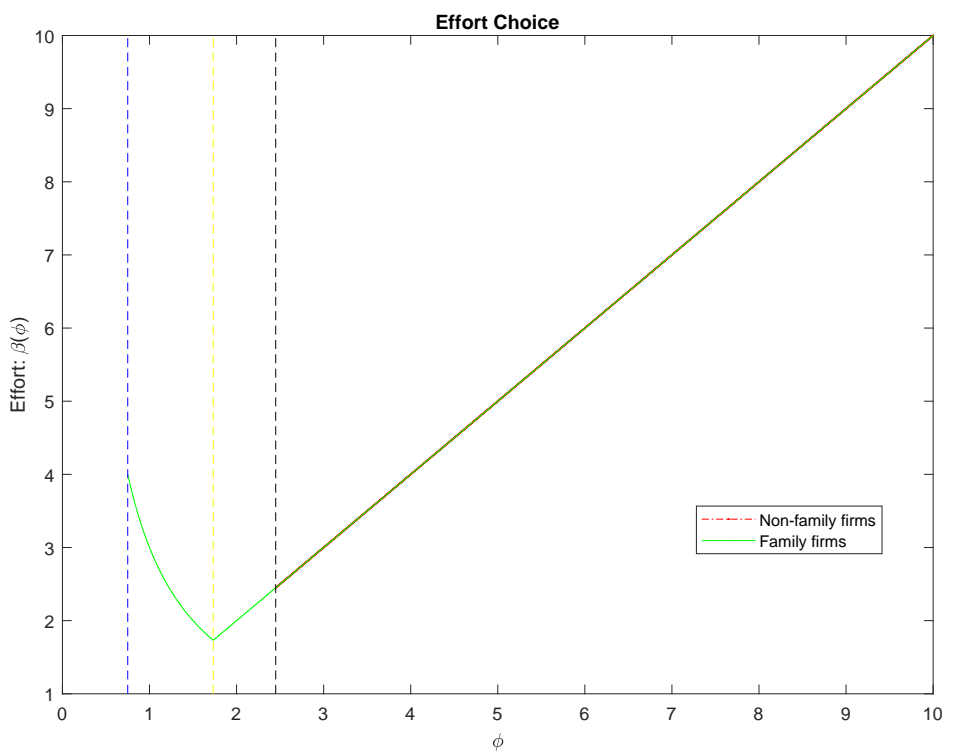

Notes:

- - - denotes $\phi_{F}$, the exit cutoff for F-type firms denotes $\bar{\phi}_{F}$, the kink point for F-type firms

--- denotes $\underline{\phi}_{P}$, the exit cutoff for P-type firms

Parameter values: $\bar{U}=8, f=5, \eta=2$. 
Figure 5: Realized log productivity across firms

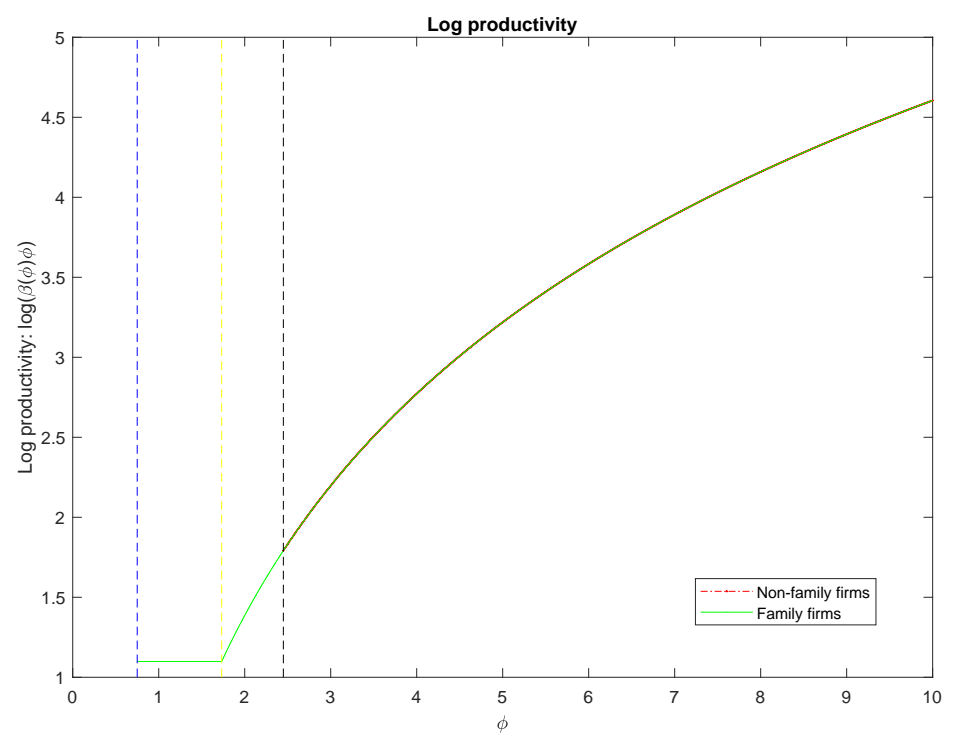

Notes:

--- denotes $\phi_{F}$, the exit cutoff for F-type firms denotes $\bar{\phi}_{F}$, the kink point for F-type firms

- - - denotes $\underline{\phi}_{P}$, the exit cutoff for P-type firms

Parameter values: $\bar{U}=8, f=5, \eta=2$. 
Figure 6: Effect of increased import competition on managerial effort and realized productivity
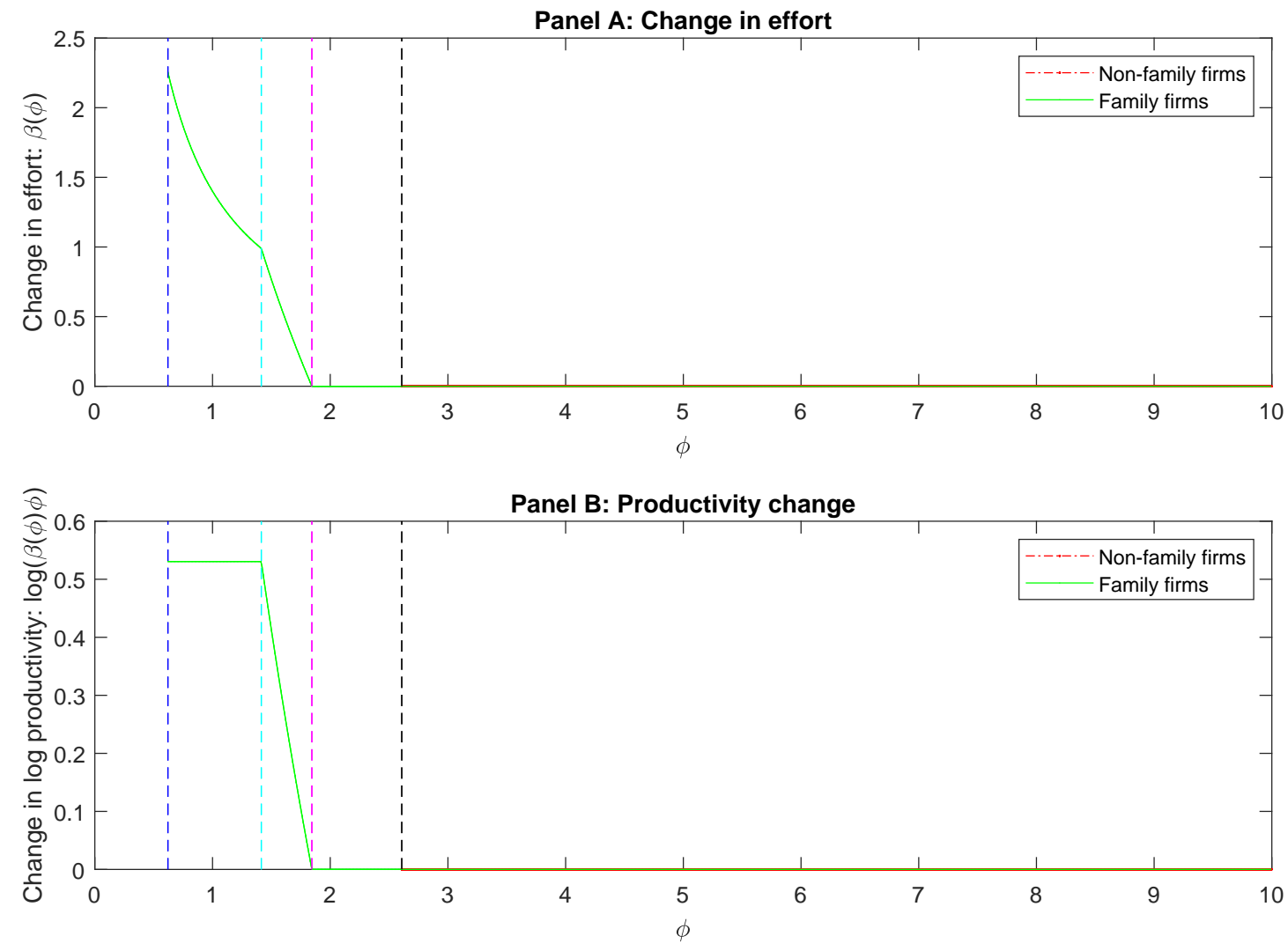

Notes:

- - - denotes $\phi_{F}^{A}$, the exit cutoff for F-type firms after import competition increases

- - denotes $\bar{\phi}_{F}^{B}$, the kink point for F-type firms before import competition increases

- - denotes $\bar{\phi}_{F}^{A}$, the kink point for F-type firms after import competition increases

- - denotes $\phi_{P}^{A}$, the exit cutoff for P-type firms after import competition increases

Parameter values: $\bar{U}=15, f=5, \eta^{B}=3, \eta^{A}=1.6$. 
Figure 7: Effect of increased import competition on managerial effort and realized productivity when the fixed cost differs between $F$-type firms and $P$-type firms
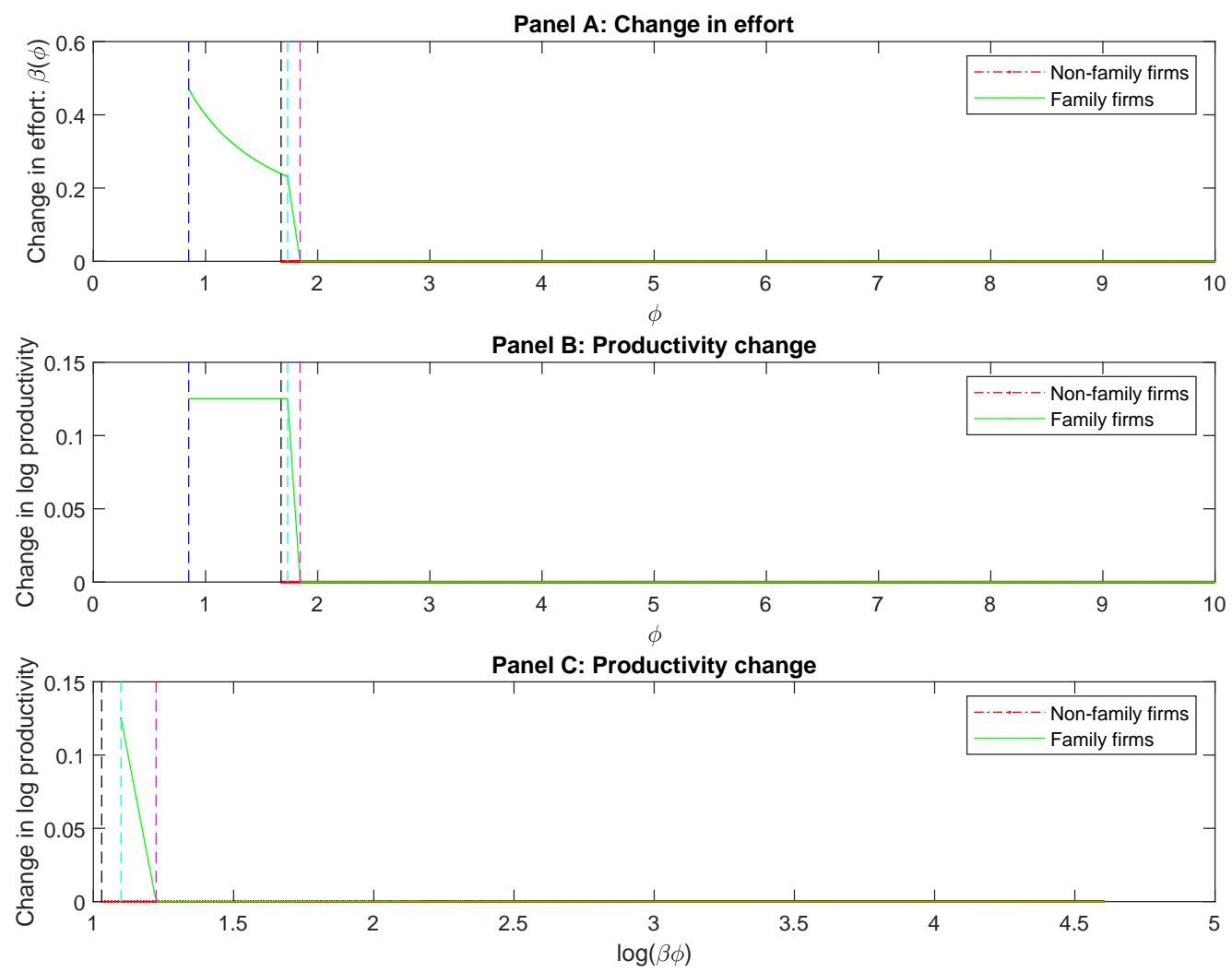

Notes:

\section{Panels A and B:}

- - denotes $\phi_{F}^{A}$, the exit cutoff for F-type firms after import competition increases

-- denotes $\bar{\phi}_{F}^{B}$, the kink point for F-type firms before import competition increases

--- denotes $\bar{\phi}_{F}^{A}$, the kink point for F-type firms after import competition increases

--- denotes $\phi_{P}^{A}$, the exit cutoff for P-type firms after import competition increases

\section{Panel C:}

- - - denotes $\ln (\beta(\phi) \phi)_{P}^{A}$, the $\log$ realized productivity of P-type firms at the exit cutoff after the shock

- - denotes $\ln (\beta(\bar{\phi}) \bar{\phi})_{F}^{B}$, the log realized productivity of F-type firms at the kink point before the shock

- - denotes $\ln (\beta(\bar{\phi}) \bar{\phi})_{F}^{A}$, the log realized productivity of F-type firms at the kink point after the shock

Parameter values: $\bar{U}=8, f_{P}=3 f_{F}=5, \eta^{B}=2, \eta^{A}=1.6$. 
Figure 8: Empirical CDF of log labor productivity

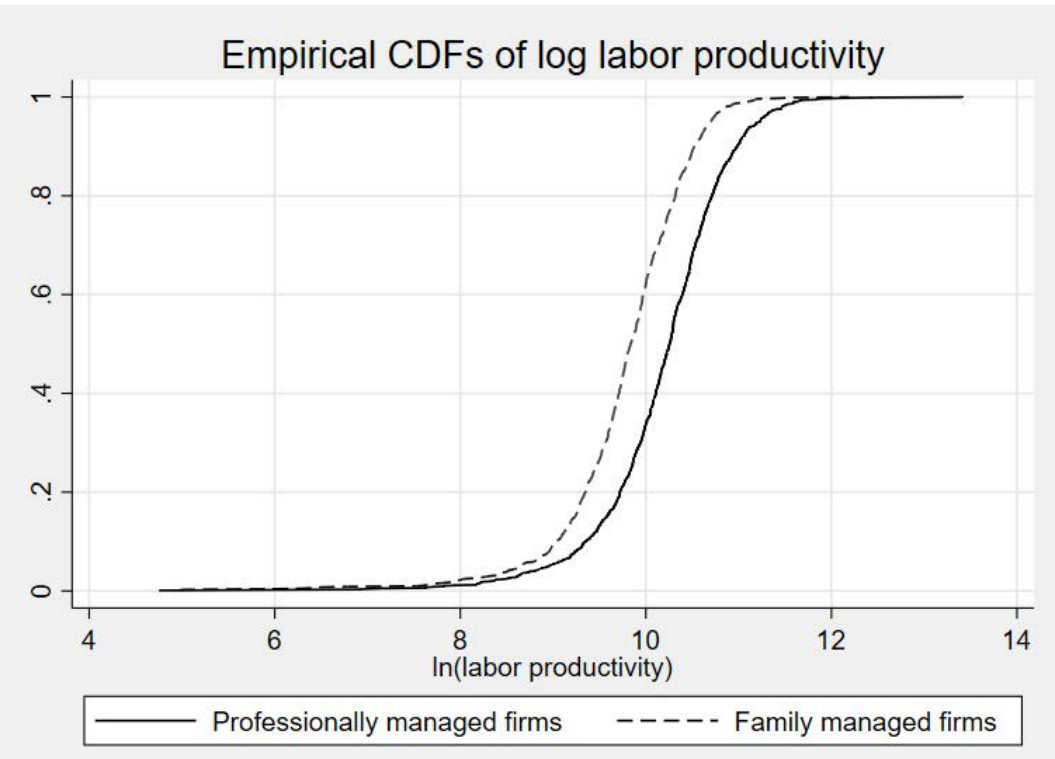

Figure 9: Effect of import competition on exit probabilities, by initial productivity

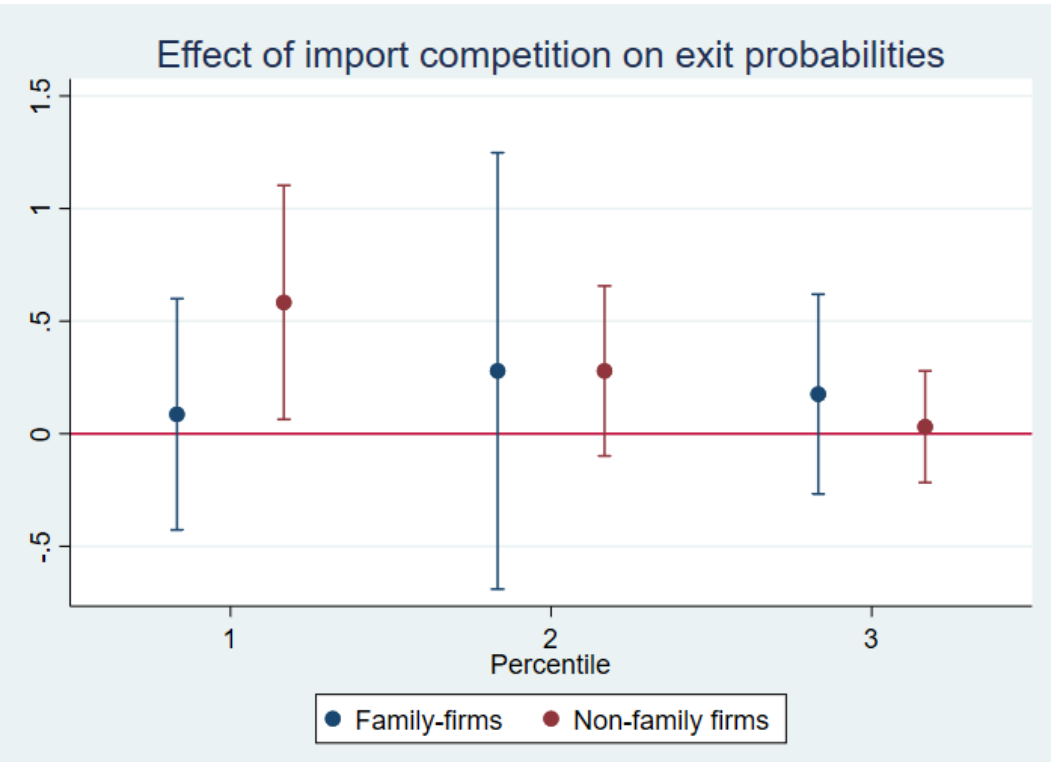




\section{A Tables}

Table 1: Descriptive statistics of Spanish manufacturing firms, family versus non-family firms

\begin{tabular}{lcccc}
\hline \hline & $\begin{array}{c}\text { Family } \\
\text { firms }\end{array}$ & $\begin{array}{c}\text { Non-family } \\
\text { firms }\end{array}$ & Difference & $\begin{array}{c}\text { Difference excl. } \\
\text { industry FEs }\end{array}$ \\
\hline \multirow{2}{*}{ N (firm-year observations) } & 6,894 & 9,812 & & \\
& $(41 \%)$ & $(59 \%)$ & & \\
Sales, million EUR & 9.50 & 84.14 & $74.64 * * *$ & $56.62 * * *$ \\
& $(0.36)$ & $(2.83)$ & & \\
Employment & 71.94 & 399.18 & $327.24 * * *$ & $260.48^{* * * *}$ \\
& $(1.95)$ & $(9.32)$ & & \\
ln(labor productivity) & 11.19 & 11.65 & $0.46^{* * * *}$ & $0.34 * * *$ \\
& $(0.01)$ & $(0.01)$ & & \\
R\&D intensity & 0.51 & 0.89 & $0.38^{* * * *}$ & $0.14 * * *$ \\
Capital intensity & $(0.02)$ & $(0.03)$ & & \\
& 26.45 & 64.13 & $37.68^{* * * *}$ & $29.71^{* * *}$ \\
\hline \hline
\end{tabular}

Notes: $* \mathrm{p}<0.05, * * \mathrm{p}<0.01, * * * \mathrm{p}<0.001$. R\&D intensity is equal to $\mathrm{R} \& \mathrm{D}$ expenditure (in EUR)/sales (in EUR)*100. Capital intensity is capital (in thousand EUR)/employment. "Difference excluding industry fixed effects" denotes the coefficient of a regression of the variable on a family firm dummy, controlling for industry fixed effects. 
Table 2: Effect of import competition on labor productivity — separate regressions

\begin{tabular}{|c|c|c|c|c|c|c|c|c|}
\hline \multirow[t]{2}{*}{ (Dep var: $\Delta \ln \left(\right.$ labprod $\left._{i t}\right)$} & (1) & (2) & (3) & (4) & (5) & (6) & (7) & (8) \\
\hline & \multicolumn{4}{|c|}{ Family firms } & \multicolumn{4}{|c|}{ Non-family firms } \\
\hline$\Delta I M P_{s t}$ & $\begin{array}{c}2.078 * * \\
(0.838)\end{array}$ & $\begin{array}{c}23.201 * * \\
(10.341)\end{array}$ & $\begin{array}{c}23.347 * * \\
(10.593)\end{array}$ & $\begin{array}{c}29.540 * * \\
(13.181)\end{array}$ & $\begin{array}{l}-1.062 \\
(0.912)\end{array}$ & $\begin{array}{c}-4.137 \\
(12.376)\end{array}$ & $\begin{array}{c}-4.199 \\
(12.500)\end{array}$ & $\begin{array}{c}-3.341 \\
(13.540)\end{array}$ \\
\hline$\Delta I M P_{s t} \cdot \ln \left(\right.$ labprod $\left.93_{i}\right)$ & & $\begin{array}{c}-2.088 * * \\
(1.022)\end{array}$ & $\begin{array}{c}-2.102 * * \\
(1.022)\end{array}$ & $\begin{array}{c}-2.668 * * \\
(1.285)\end{array}$ & & $\begin{array}{c}0.296 \\
(1.172)\end{array}$ & $\begin{array}{c}0.301 \\
(1.183)\end{array}$ & $\begin{array}{c}0.239 \\
(1.278)\end{array}$ \\
\hline $\ln \left(\right.$ labprod $\left.93_{i}\right)$ & $\begin{array}{c}-0.063 * * * \\
(0.023)\end{array}$ & $\begin{array}{c}-0.057 * * \\
(0.024)\end{array}$ & $\begin{array}{c}-0.058^{* *} \\
(0.026)\end{array}$ & & $\begin{array}{c}-0.065^{* * *} \\
(0.011)\end{array}$ & $\begin{array}{c}-0.066^{* * *} \\
(0.013)\end{array}$ & $\begin{array}{c}-0.068^{* * *} \\
(0.014)\end{array}$ & \\
\hline \multicolumn{9}{|l|}{ Effects evaluated at: } \\
\hline 10th prod percentile & $\mathrm{n} / \mathrm{a}$ & $\begin{array}{c}4.013 * * * \\
(1.239)\end{array}$ & $\begin{array}{c}4.033 * * * \\
(1.262)\end{array}$ & $\begin{array}{c}5.024 * * * \\
(1.615)\end{array}$ & $\mathrm{n} / \mathrm{a}$ & $\begin{array}{l}-1.413 \\
(1.815)\end{array}$ & $\begin{array}{l}-1.429 \\
(1.832)\end{array}$ & $\begin{array}{l}-1.144 \\
(2.015)\end{array}$ \\
\hline 90th prod percentile & $\mathrm{n} / \mathrm{a}$ & $\begin{array}{c}0.651 \\
(1.104)\end{array}$ & $\begin{array}{c}0.649 \\
(1.108)\end{array}$ & $\begin{array}{c}0.729 \\
(1.145)\end{array}$ & $\mathrm{n} / \mathrm{a}$ & $\begin{array}{l}-0.936 \\
(0.949)\end{array}$ & $\begin{array}{l}-0.944 \\
(0.945)\end{array}$ & $\begin{array}{l}-0.760 \\
(1.025)\end{array}$ \\
\hline Observations & 6,507 & 6,507 & 6,507 & 6,434 & 7,834 & 7,834 & 7,834 & 7,759 \\
\hline Industry FE & yes & yes & yes & & yes & yes & yes & \\
\hline Region FE & & & yes & & & & yes & \\
\hline Firm FE & & & & yes & & & & yes \\
\hline Number of firmid & & & & 662 & & & & 822 \\
\hline
\end{tabular}

Notes: $* \mathrm{p}<0.05, * * \mathrm{p}<0.01, * * * \mathrm{p}<0.001$. Standard errors in parentheses are two-way clustered (by industry-year pairs and firms). All regressions include year fixed effects. Marginal effects are calculated as $\frac{\partial \Delta \ln \left(\text { labprod }_{i t}\right)}{\partial \Delta I M P_{s t}}=\beta_{1}+\beta_{2} \ln \left({\left.\text { labprod } 93_{i}\right)}_{i}\right.$ as specified in regression equation (1) and evaluated at the 10th and 90th percentile of the initial productivity distribution (across all firms; i.e., including both family and nonfamily firms). 
Table 3: Effect of import competition — pooled regression

\begin{tabular}{|c|c|c|c|c|}
\hline Dependent variable: & $\begin{array}{c}(1) \\
\Delta \ln \left(\text { labprod }_{i t}\right)\end{array}$ & $\begin{array}{c}\text { (2) } \\
\Delta \ln \left(\text { labprod }_{i t}\right)\end{array}$ & $\begin{array}{c}(3) \\
\Delta \ln \left(\text { labprod }_{i t}\right)\end{array}$ & $\begin{array}{c}(4) \\
\Delta \ln \left(\text { labprod }_{i t}\right)\end{array}$ \\
\hline \multirow[t]{2}{*}{$\Delta I M P_{s t}$} & -4.137 & -4.199 & & -3.693 \\
\hline & $(12.376)$ & (12.500) & & (13.779) \\
\hline \multirow[t]{2}{*}{$\Delta I M P_{s t} \cdot \ln \left(\right.$ labprod $\left.93_{i}\right)$} & 0.296 & 0.301 & -0.102 & 0.260 \\
\hline & $(1.172)$ & $(1.183)$ & $(0.120)$ & $(1.300)$ \\
\hline \multirow{2}{*}{$\Delta I M P_{s t} \cdot F A M 93_{i}$} & $27.338 *$ & $27.546^{*}$ & $23.453 * *$ & $31.302 *$ \\
\hline & $(15.920)$ & $(16.095)$ & (11.736) & (18.834) \\
\hline \multirow[t]{2}{*}{$\Delta I M P_{s t} \cdot \ln \left(\right.$ labprod $\left.93_{i}\right) \cdot F A M 93_{i}$} & -2.385 & -2.404 & $-2.032 *$ & -2.735 \\
\hline & $(1.551)$ & $(1.567)$ & (1.197) & $(1.821)$ \\
\hline \multirow[t]{2}{*}{$F A M 93_{i}$} & -0.121 & -0.088 & -0.253 & \\
\hline & $(0.234)$ & $(0.248)$ & $(0.229)$ & \\
\hline \multirow[t]{2}{*}{$\ln \left(\right.$ labprod $\left.93_{i}\right) \cdot F A M 93_{i}$} & 0.009 & 0.010 & 0.009 & \\
\hline & $(0.023)$ & $(0.024)$ & $(0.023)$ & \\
\hline \multirow[t]{2}{*}{$\ln \left(\right.$ labprod $\left.93_{i}\right)$} & $-0.066 * * *$ & $-0.068 * * *$ & $-0.065^{* * *}$ & \\
\hline & $(0.013)$ & $(0.014)$ & $(0.011)$ & \\
\hline \multicolumn{5}{|l|}{ Marginal effects: } \\
\hline \multirow[t]{2}{*}{ Non-family firms, p10 } & -1.413 & -1.429 & & -1.307 \\
\hline & $(1.815)$ & $(1.832)$ & & $(2.058)$ \\
\hline \multirow[t]{2}{*}{ Non-family firms, p90 } & -0.936 & -0.944 & & -0.890 \\
\hline & $(0.949)$ & $(0.945)$ & & $(1.037)$ \\
\hline \multirow[t]{2}{*}{ Family firms, p10 } & $4.013 * * *$ & $4.033 * * *$ & & $4.866 * * *$ \\
\hline & $(1.239)$ & $(1.262)$ & & $(1.728)$ \\
\hline \multirow[t]{2}{*}{ Family firms, p90 } & 0.651 & 0.649 & & 0.881 \\
\hline & $(1.104)$ & $(1.108)$ & & $(1.236)$ \\
\hline Family versus non-family firms, & $5.426 * * *$ & $5.462 * * *$ & $4.785 * * *$ & $6.173 * *$ \\
\hline $\mathrm{p} 10$ & $(2.089)$ & $(2.110)$ & $(1.350)$ & $(2.532)$ \\
\hline Family versus non-family firms, & 1.587 & 1.593 & 1.515 & 1.771 \\
\hline p 90 & $(1.593)$ & $(1.590)$ & $(1.704)$ & (1.739) \\
\hline Observations & 14,341 & 14,341 & 14,341 & 14,195 \\
\hline Region $*$ famfirm FE & & yes & & \\
\hline Industry * year FE & & & yes & \\
\hline Firm FE & & & & yes \\
\hline
\end{tabular}

Notes: $* \mathrm{p}<0.05, * * \mathrm{p}<0.01, * * * \mathrm{p}<0.001$. Standard errors in parentheses are two-way clustered (by industry-year pairs and firms). All regressions include family-firm specific industry and year fixed effects. Family firms are indicated by a dummy variable. There are 17 regions in our data (corresponding to autonomous regions in Spain). We estimate regression equation (2) and calculate the marginal effects for non-family firms as $\left.\frac{\partial \Delta \ln \left(\text { labprod }_{i t}\right)}{\partial \Delta I M P_{s t}}\right|_{F A M 93_{i}=0}=\beta_{1}+\beta_{2} \ln \left({\left.\text { labprod } 93_{i}\right)}_{i}\right.$ and the ones for family-firms as $\left.\frac{\partial \Delta \ln \left(\text { labprod }_{i t}\right)}{\partial \Delta I M P_{s t}}\right|_{F A M 93_{i}=1}=\beta_{1}+\beta_{3}+\left(\beta_{2}+\beta_{4}\right) \ln \left(\right.$ labprod $\left.93_{i}\right)$, while the marginal differential effects for family versus nonfamily firms are given by $\left.\frac{\partial \Delta \ln \left(\text { labprod }_{i t}\right)}{\partial \Delta I M P_{s t}}\right|_{F A M 93_{i}=1}-\left.\frac{\partial \Delta \ln \left(\text { labprod }_{i t}\right)}{\partial \Delta I M P_{s t}}\right|_{F A M 93_{i}=0}=\beta_{3}+\beta_{4} \ln \left(\right.$ labprod $\left._{9} 3_{i}\right)$. We evaluate all marginal effects at the 10th and 90th percentile of the initial productivity distribution (i.e., across non-family and family firms). 
Table 4: Horse race between family management and other observable firm characteristics

\begin{tabular}{|c|c|c|c|c|c|c|}
\hline Dependent variable: & $\begin{array}{c}(1) \\
\Delta \ln \left(\text { labprod }_{i t}\right)\end{array}$ & $\begin{array}{c}(2) \\
\Delta \ln \left(\text { labprod }_{i t}\right)\end{array}$ & $\begin{array}{c}(3) \\
\Delta \ln \left(\text { labprod }_{i t}\right)\end{array}$ & $\begin{array}{c}(4) \\
\Delta \ln \left(\text { labprod }_{i t}\right) \\
\end{array}$ & $\begin{array}{c}(5) \\
\Delta \ln \left(\text { labprod }_{i t}\right)\end{array}$ & $\begin{array}{c}(6) \\
\Delta \ln \left(\text { labprod }_{i t}\right) \\
\end{array}$ \\
\hline \multirow[t]{2}{*}{$\Delta I M P_{s t}$} & -4.137 & 37.513 & -8.486 & -3.335 & -12.283 & 175.578 \\
\hline & (12.376) & (70.806) & (32.836) & (12.454) & (11.566) & $(154.703)$ \\
\hline \multirow[t]{2}{*}{$\Delta I M P_{s t} \cdot \ln \left(\right.$ labprod $\left.93_{i}\right)$} & 0.296 & -3.861 & 0.567 & 0.186 & 1.150 & -15.773 \\
\hline & $(1.172)$ & $(6.894)$ & $(3.243)$ & $(1.179)$ & $(1.111)$ & (14.759) \\
\hline \multirow{2}{*}{$\Delta I M P_{s t} \cdot F A M 93_{i}$} & $27.338^{*}$ & $26.041^{*}$ & $29.836^{* *}$ & $29.729 *$ & $32.872 * *$ & $43.473 * * *$ \\
\hline & $(15.920)$ & $(15.813)$ & $(14.337)$ & (15.885) & $(15.937)$ & $(16.502)$ \\
\hline \multirow[t]{2}{*}{$\Delta I M P_{s t} \cdot \ln \left(\right.$ labprod $\left.93_{i}\right) \cdot F A M 93_{i}$} & -2.385 & -2.252 & $-2.593^{*}$ & $-2.619^{*}$ & $-2.944 *$ & $-3.943^{* *}$ \\
\hline & $(1.551)$ & $(1.540)$ & $(1.424)$ & $(1.545)$ & $(1.562)$ & $(1.638)$ \\
\hline \multirow[t]{2}{*}{$\Delta I M P_{\text {st }} \cdot \ln \left(\right.$ sales $\left.93_{i}\right)$} & & -2.487 & & & & -18.914 \\
\hline & & $(4.331)$ & & & & (15.984) \\
\hline \multirow[t]{2}{*}{$\Delta I M P_{\text {st }} \cdot \ln \left(\right.$ labprod $\left.93_{i}\right) \cdot \ln \left(\right.$ sales $\left.93_{i}\right)$} & & 0.247 & & & & 1.701 \\
\hline & & $(0.411)$ & & & & $(1.522)$ \\
\hline \multirow[t]{2}{*}{$\Delta I M P_{s t} \cdot \ln \left(e m p l 93_{i}\right)$} & & & 1.522 & & & 20.868 \\
\hline & & & (7.468) & & & (20.885) \\
\hline \multirow[t]{2}{*}{$\Delta I M P_{s t} \cdot \ln \left(\right.$ labprod $\left.93_{i}\right) \cdot \ln ($ empl93 $)$} & & & -0.117 & & & -1.860 \\
\hline & & & $(0.720)$ & & & $(2.023)$ \\
\hline \multirow{2}{*}{$\Delta I M P_{s t} \cdot \ln \left(R \& D i n t 93_{i}\right)$} & & & & -2.242 & & -1.808 \\
\hline & & & & $(3.661)$ & & $(3.575)$ \\
\hline \multirow[t]{2}{*}{$\Delta I M P_{s t} \cdot \ln \left(\right.$ labprod $\left.93_{i}\right) \cdot \ln \left(R \&\right.$ Dint $\left.93_{i}\right)$} & & & & 0.247 & & 0.199 \\
\hline & & & & $(0.358)$ & & $(0.350)$ \\
\hline \multirow[t]{2}{*}{$\Delta I M P_{\text {st }} \cdot \ln \left(\right.$ capint $\left.93_{i}\right)$} & & & & & 0.000 & 0.000 \\
\hline & & & & & $(0.000)$ & $(0.000)$ \\
\hline \multirow[t]{2}{*}{$\Delta I M P_{s t} \cdot \ln \left(\right.$ labprod $\left.93_{i}\right) \cdot \ln \left(\right.$ capint $\left.93_{i}\right)$} & & & & & -0.000 & -0.000 \\
\hline & & & & & $(0.000)$ & $(0.000)$ \\
\hline \multicolumn{7}{|l|}{ Marginal effects: } \\
\hline Family versus non-family firms, & $5.426 * * *$ & $5.346 * * *$ & $6.014 * * *$ & $5.662 * * *$ & $5.821 * * *$ & $7.241 * * *$ \\
\hline p 10 & $(2.089)$ & $(2.014)$ & $(1.667)$ & $(2.086)$ & $(2.004)$ & $(1.834)$ \\
\hline Family versus non-family firms, & 1.587 & 1.721 & 1.841 & 1.446 & 1.081 & 0.893 \\
\hline p 90 & $(1.593)$ & $(1.482)$ & $(1.577)$ & $(1.546)$ & $(1.624)$ & $(1.691)$ \\
\hline Observations & 14,341 & 14,341 & 14,341 & 14,185 & 13,665 & 13,516 \\
\hline
\end{tabular}

Notes: $* \mathrm{p}<0.05, * * \mathrm{p}<0.01, * * * \mathrm{p}<0.001$. Standard errors in parentheses are two-way clustered (by industryyear pairs and firms). Family firms are indicated by a dummy variable. All regressions include family-firm specific industry and year fixed effects, as well as a family firm dummy, a family firm dummy interacted with initial productivity, initial productivity, the horserace variable, and the horse race variable interacted with initial productivity. sales 93 is total firm sales in 1993. empl93 is total employment in 1993. of R\&Dint93 is R\&D intensity (R\&D expenditure/sales) in 1993. capint93 is capital intensity (capital/employment) in 1993 . We estimate regression equation (2) and calculate the marginal differential effects for family versus non-family firms by $\left.\frac{\partial \Delta \ln \left(\text { labprod }_{i t}\right)}{\partial \Delta I M P_{s t}}\right|_{F A M 93_{i}=1}-\left.\frac{\partial \Delta \ln \left(\text { (labprod }_{i t}\right)}{\partial \Delta I M P_{s t}}\right|_{F A M 93_{i}=0}=\beta_{3}+\beta_{4} \ln \left({\left.\text { labprod } 93_{i}\right)}_{i}\right.$, evaluated at the 10th and 90th percentile of the initial productivity distribution (i.e., across non-family and family firms). 
Table 5: Managing versus non-managing family members

\begin{tabular}{|c|c|c|c|c|}
\hline $\begin{array}{l}\text { Dependent variable: } \Delta \ln \left(\text { labprod }_{i t}\right) \\
\text { Family members }\end{array}$ & $\begin{array}{c}\text { (1) } \\
\text { dummy }\end{array}$ & $\begin{array}{c}\text { (2) } \\
\text { dummy }\end{array}$ & $\begin{array}{c}\text { (3) } \\
\text { number }\end{array}$ & $\begin{array}{c}\text { (4) } \\
\text { number }\end{array}$ \\
\hline$\Delta I M P_{s t}$ & $\begin{array}{c}-4.137 \\
(12.376)\end{array}$ & $\begin{array}{c}-3.583 \\
(12.439)\end{array}$ & $\begin{array}{c}-1.574 \\
(11.025)\end{array}$ & $\begin{array}{c}-1.366 \\
(11.258)\end{array}$ \\
\hline$\Delta I M P_{s t} \cdot \ln \left(\right.$ labprod $\left.93_{i}\right)$ & $\begin{array}{c}0.296 \\
(1.172)\end{array}$ & $\begin{array}{c}0.239 \\
(1.176)\end{array}$ & $\begin{array}{c}0.109 \\
(1.039)\end{array}$ & $\begin{array}{c}0.082 \\
(1.060)\end{array}$ \\
\hline$\Delta I M P_{s t} \cdot F A M M G R 93_{i}$ & $\begin{array}{l}27.338^{*} \\
(15.920)\end{array}$ & $\begin{array}{c}27.316 \\
(16.894)\end{array}$ & $\begin{array}{c}18.241 * * \\
(8.660)\end{array}$ & $\begin{array}{c}18.228 * * \\
(9.223)\end{array}$ \\
\hline$\Delta I M P_{s t} \cdot \ln \left({\left.\text { labprod } 93_{i}\right)}\right) \cdot F A M M G R 93_{i}$ & $\begin{array}{l}-2.385 \\
(1.551)\end{array}$ & $\begin{array}{l}-2.389 \\
(1.646)\end{array}$ & $\begin{array}{c}-1.711^{* *} \\
(0.840)\end{array}$ & $\begin{array}{l}-1.713^{*} \\
(0.896)\end{array}$ \\
\hline$\Delta I M P_{s t} \cdot F A M N O M G R 93_{i}$ & & $\begin{array}{c}-5.196 \\
(12.706)\end{array}$ & & $\begin{array}{c}-4.588 \\
(12.823)\end{array}$ \\
\hline$\Delta I M P_{s t} \cdot \ln \left(\right.$ labprod $\left.93_{i}\right) \cdot F A M N O M G R 93_{i}$ & & $\begin{array}{c}0.563 \\
(1.212)\end{array}$ & & $\begin{array}{c}0.522 \\
(1.227)\end{array}$ \\
\hline$F A M M G R 93_{i}$ & $\begin{array}{l}-0.121 \\
(0.234)\end{array}$ & $\begin{array}{l}-0.074 \\
(0.261)\end{array}$ & $\begin{array}{l}-0.020 \\
(0.110)\end{array}$ & $\begin{array}{l}-0.006 \\
(0.117)\end{array}$ \\
\hline $\ln \left(\right.$ labprod $\left.93_{i}\right) \cdot F A M M G R 93_{i}$ & $\begin{array}{c}0.009 \\
(0.023)\end{array}$ & $\begin{array}{c}0.005 \\
(0.026)\end{array}$ & $\begin{array}{c}0.002 \\
(0.011)\end{array}$ & $\begin{array}{c}0.000 \\
(0.012)\end{array}$ \\
\hline $\ln \left(\right.$ labprod $\left.93_{i}\right)$ & $\begin{array}{c}-0.066^{* * *} \\
(0.013)\end{array}$ & $\begin{array}{c}-0.066^{* * *} \\
(0.013)\end{array}$ & $\begin{array}{c}-0.063 * * * \\
(0.012)\end{array}$ & $\begin{array}{c}-0.064 * * * \\
(0.012)\end{array}$ \\
\hline \multicolumn{5}{|l|}{ Marginal effects: } \\
\hline $\begin{array}{l}\text { Family versus non-family firms, } \\
\text { p } 10\end{array}$ & $\begin{array}{c}5.426 * * * \\
(2.089)\end{array}$ & $\begin{array}{l}5.367^{* *} \\
(2.165)\end{array}$ & $\begin{array}{l}4.068 * * \\
(1.824)\end{array}$ & $\begin{array}{r}4.020^{* *} \\
(1.886)\end{array}$ \\
\hline $\begin{array}{l}\text { Family versus non-family firms, } \\
\text { p } 90\end{array}$ & $\begin{array}{c}1.587 \\
(1.593)\end{array}$ & $\begin{array}{c}1.522 \\
(1.608)\end{array}$ & $\begin{array}{l}-0.375 \\
(1.274)\end{array}$ & $\begin{array}{l}-0.427 \\
(1.321)\end{array}$ \\
\hline Observations & 14,341 & 14,341 & 14,341 & 14,341 \\
\hline
\end{tabular}

Notes: $* \mathrm{p}<0.05, * * \mathrm{p}<0.01, * * * \mathrm{p}<0.001$. Standard errors in parentheses are two-way clustered (by industry-year pairs and firms). All regressions include family-firm specific industry and year fixed effects. FAMMGR93 ${ }_{i}$ in columns (1) and (2) is a dummy variable if the firm has family managers, and in column (3) and (4) it is the number of family managers. FAMNOMGR93 ${ }_{i}$ in columns (1) and (2) is a dummy variable if the firm has family members in non-managing positions, and in column (3) and (4) it is the number of family members in non-managing positions. Columns (2) and (4) also include FAMNOMGR93 ${ }_{i}$ and its interaction with productivity. The marginal effects for family firms are computed for family firms with the average number of family managers (1.6). We estimate regression equation (2) and calculate the marginal differential effects for family versus non-family firms by $\left.\frac{\partial \Delta \ln \left(\text { labprod }_{i t}\right)}{\partial \Delta I M P_{s t}}\right|_{F A M 93_{i}=1}-\left.\frac{\partial \Delta \ln \left(\text { labprod }_{i t}\right)}{\partial \Delta I M P_{s t}}\right|_{F A M 93_{i}=0}=\beta_{3}+\beta_{4} \ln \left({\left.\text { labprod } 93_{i}\right)}_{i}\right.$, evaluated at the 10 th and 90th percentile of the initial productivity distribution (i.e., across non-family and family firms). 
Table 6: Family ownership and management changes

\begin{tabular}{lcccc}
\hline \hline & $(1)$ & $(2)$ & $(3)$ & $(4)$ \\
Dependent variable: & $\Delta \ln \left(\right.$ labprod $\left._{i t}\right)$ & $\Delta \ln \left(\right.$ labprod $\left._{i t}\right)$ & $\Delta \ln \left(\right.$ labprod $\left._{i t}\right)$ & $\begin{array}{c}\text { Change in } \\
\text { family mgmt }\end{array}$ \\
\hline Marginal effects: & & & & \\
Family versus non-family firms, & $5.426^{* * *}$ & $10.399^{*}$ & $10.779^{* * *}$ & 1.677 \\
p 10 & $(2.089)$ & $(5.473)$ & $(4.027)$ & $(2.116)$ \\
Family versus non-family firms, & 1.587 & 3.076 & -3.703 & 0.671 \\
p 90 & $(1.593)$ & $(3.155)$ & $(4.677)$ & $(1.172)$ \\
& & & & 14,341 \\
Observations & 14,341 & 3,086 & 8,885 & all \\
Sample & all & family owned & non-switchers & \\
\hline \hline
\end{tabular}

Notes: $* \mathrm{p}<0.05, * * \mathrm{p}<0.01, * * * \mathrm{p}<0.001$. Standard errors in parentheses are two-way clustered (by industryyear pairs and firms). All regressions include family-firm specific industry and year fixed effects. Sample "family owned" restricts the sample to firms that are family owned in 2006 (earlier information about family ownership is unfortunately not available in the data). Sample "non-switchers" drops family firms that change to professional management at some point in the sample. We estimate regression equation (2) and calculate the marginal differential effects for family versus non-family firms by $\left.\frac{\partial \Delta \ln \left(\text { (abprod }_{i t}\right)}{\partial \Delta I M P_{s t}}\right|_{F A M 93_{i}=1}$ $\left.\frac{\partial \Delta \ln \left(\text { labprod }_{i t}\right)}{\partial \Delta I M P_{s t}}\right|_{F A M 93_{i}=0}=\beta_{3}+\beta_{4} \ln \left({\left.\text { labprod } 93_{i}\right)}_{1}\right.$, evaluated at the 10th and 90th percentile of the initial productivity distribution (i.e., across non-family and family firms). Regression coefficients are not reported to save space. 
Table 7: Mechanism: R\&D and innovation related outcomes

\begin{tabular}{|c|c|c|c|c|}
\hline Dependent variable: & $\Delta \ln \left(\right.$ labprod $\left._{i t}\right)$ & $\begin{array}{c}(2) \\
\text { Change } \\
\text { R\&D dummy }\end{array}$ & $\Delta \ln \left(R \& D e x p_{i t}\right)$ & $\begin{array}{c}\text { (4) } \\
\text { Change in } \\
\text { \# patents }\end{array}$ \\
\hline \multicolumn{5}{|l|}{ Marginal effects: } \\
\hline $\begin{array}{l}\text { Family versus non-family firms, } \\
\text { p } 10\end{array}$ & $\begin{array}{l}5.426 * * * \\
(2.089)\end{array}$ & $\begin{array}{l}-0.782 \\
(1.038)\end{array}$ & $\begin{array}{l}3.118 \\
(8.946)\end{array}$ & $\begin{array}{l}12.159 \\
(8.883)\end{array}$ \\
\hline $\begin{array}{l}\text { Family versus non-family firms, } \\
\text { p } 90\end{array}$ & $\begin{array}{c}1.587 \\
(1.593)\end{array}$ & $\begin{array}{l}-0.333 \\
(1.019)\end{array}$ & $\begin{array}{l}4.942 \\
(3.485)\end{array}$ & $\begin{array}{l}-11.555 \\
(10.635)\end{array}$ \\
\hline Observations & 14,341 & 14,169 & 4,769 & 14,283 \\
\hline
\end{tabular}

Notes: $* \mathrm{p}<0.05, * * \mathrm{p}<0.01, * * * \mathrm{p}<0.001$. Standard errors in parentheses are two-way clustered (by industryyear pairs and firms). All regressions include family-firm specific industry and year fixed effects. Family firms are indicated by a dummy variable. We estimate regression equation (2) and calculate the marginal differential effects for family versus non-family firms by $\left.\frac{\partial \Delta \ln \left(\text { labprod }_{i t}\right)}{\partial \Delta I M P_{s t}}\right|_{F A M 93_{i}=1}-\left.\frac{\partial \Delta \ln \left(\text { labprod }_{i t}\right)}{\partial \Delta I M P_{s t}}\right|_{F A M 93_{i}=0}=\beta_{3}+$ $\beta_{4} \ln \left(\right.$ labprod $\left.93_{i}\right)$, evaluated at the 10th and 90th percentile of the initial productivity distribution (i.e., across non-family and family firms). Regression coefficients are not reported to save space. Note that results in column (1) are robust to using the samples in columns (2) to (4).

Table 8: Decomposition of effect

\begin{tabular}{|c|c|c|c|c|c|c|c|}
\hline Dependent variable: & $\begin{array}{c}(1) \\
\Delta \ln \left(\text { labprod }_{i t}\right)\end{array}$ & $\begin{array}{c}(2) \\
\Delta \ln \left(\text { valueadded }_{i t}\right)\end{array}$ & $\begin{array}{c}(3) \\
\Delta \ln \left(\text { sales }_{i t}\right)\end{array}$ & $\begin{array}{c}(4) \\
\Delta \ln \left(\text { material }_{i t}\right)\end{array}$ & $\begin{array}{c}(5) \\
\Delta \ln \left(e m p l_{i t}\right)\end{array}$ & $\begin{array}{c}(6) \\
\Delta \ln \left(c^{\prime} a p_{i t}\right) \\
\end{array}$ & $\begin{array}{c}(7) \\
\Delta \ln \left(\text { profit }_{i t}\right)\end{array}$ \\
\hline \multicolumn{8}{|l|}{ Marginal effects: } \\
\hline $\begin{array}{l}\text { Family versus } \\
\text { non-family firms, p } 10\end{array}$ & $\begin{array}{c}5.426 * * * \\
(2.089)\end{array}$ & $\begin{array}{c}5.594 * * * \\
(1.843)\end{array}$ & $\begin{array}{l}-0.675 \\
(1.074)\end{array}$ & $\begin{array}{l}-3.001 * \\
(1.592)\end{array}$ & $\begin{array}{c}0.168 \\
(1.507)\end{array}$ & $\begin{array}{l}-0.725 \\
(3.417)\end{array}$ & $\begin{array}{c}15.968 * * * \\
(4.941)\end{array}$ \\
\hline $\begin{array}{l}\text { Family versus } \\
\text { non-family firms,p } 90\end{array}$ & $\begin{array}{c}1.587 \\
(1.593)\end{array}$ & $\begin{array}{c}1.246 \\
(1.622)\end{array}$ & $\begin{array}{c}0.039 \\
(1.031)\end{array}$ & $\begin{array}{l}-0.961 \\
(1.023)\end{array}$ & $\begin{array}{l}-0.340 \\
(0.843)\end{array}$ & $\begin{array}{l}-0.091 \\
(1.990)\end{array}$ & $\begin{array}{l}7.245^{* *} \\
(2.960)\end{array}$ \\
\hline Observations & 14,341 & 14,341 & 14,341 & 14,340 & 14,341 & 14,024 & 11,438 \\
\hline
\end{tabular}

Notes: $* \mathrm{p}<0.05, * * \mathrm{p}<0.01, * * * \mathrm{p}<0.001$. Standard errors in parentheses are two-way clustered (by industryyear pairs and firms). All regressions include family-firm specific industry and year fixed effects. Family firms are indicated by a dummy variable. We estimate regression equation (2) and calculate the marginal differential effects for family versus non-family firms by $\left.\frac{\partial \Delta \ln \left(\text { labprod }_{i t}\right)}{\partial \Delta I M P_{s t}}\right|_{F A M 93_{i}=1}-\left.\frac{\partial \Delta \ln \left(\text { labprod }_{i t}\right)}{\partial \Delta I M P_{s t}}\right|_{F A M 93_{i}=0}=\beta_{3}+$ $\beta_{4} \ln \left(\right.$ labprod $\left.93_{i}\right)$, evaluated at the 10 th and 90 th percentile of the initial productivity distribution (i.e., across non-family and family firms). Regression coefficients are not reported to save space. 


\section{Table 9: Heterogeneous effects by number of family managers}

\begin{tabular}{|c|c|c|c|c|c|c|}
\hline Dependent variable: $\Delta \ln \left(\right.$ labprod $\left._{i t}\right)$ & (1) & (2) & (3) & (4) & (5) & (6) \\
\hline Sample: & Non-family firms & 1 fam mgr & $>1$ fam mgr & Non-family firms & 1 fam mgr & $>1$ fam mgr \\
\hline \multicolumn{7}{|l|}{ Marginal effects: } \\
\hline \multirow[t]{2}{*}{ 10th prod percentile } & -1.413 & $3.999 * *$ & $4.583 *$ & -1.307 & $4.084 *$ & $5.757 *$ \\
\hline & $(1.815)$ & $(1.851)$ & $(2.459)$ & $(2.058)$ & $(2.221)$ & $(3.207)$ \\
\hline \multirow[t]{2}{*}{ 90th prod percentile } & -0.936 & 0.282 & 1.058 & -0.890 & 0.824 & 0.620 \\
\hline & $(0.949)$ & $(1.278)$ & $(2.058)$ & $(1.037)$ & $(1.436)$ & $(2.235)$ \\
\hline Observations & 7,834 & 3,580 & 2,927 & 7,759 & 3,536 & 2,900 \\
\hline Firm FE & & & & yes & yes & yes \\
\hline
\end{tabular}

Notes: $* \mathrm{p}<0.05, * * \mathrm{p}<0.01, * * * \mathrm{p}<0.001$. Standard errors in parentheses are two-way clustered (by industryyear pairs and firms). All regressions include year and industry fixed effects. Marginal effects are calculated as $\frac{\partial \Delta \ln \left(\text { labprod }_{i t}\right)}{\partial \Delta I M P_{s t}}=\beta_{1}+\beta_{2} \ln \left(\right.$ labprod $\left.93_{i}\right)$ as specified in regression equation (1) and evaluated at the 10 th and 90th percentile of the initial productivity distribution (across all firms; i.e., including both family and non-family firms). Regression coefficients are not reported to save space. 


\section{B Proofs}

\section{B.1 Proof of Proposition 1}

Proof. Consider the following:

1. Solving the $P$-type manager's objective function in equation (5) yields $\beta_{P}(\phi)=\phi$. Plugging this into the utility function, the manager gets a payoff of $U_{P}(\phi)=\eta+$ $\frac{1}{2} \phi^{2}-f$ as a function of the initial productivity draw. The manager will let the firm exit (before exerting the effort) when she expects to receive a non-positive utility from running the firm; we can solve for the exit cutoff of the firm by setting $U_{P}\left(\phi_{P}\right)=0$. Solving for this means the firm exists iff $\phi \geq \phi_{P} \equiv \sqrt{2(f-\eta)}$. Because effort costs are strictly positive for positive effort, the firm's profit is strictly positive whenever the firm exists, while the $P$-type manager's payoff is only non-negative (i.e., zero at the cutoff).

2. The optimal profit function is $\beta_{P}(\phi)=\phi$ and therefore increasing in $\phi$.

3. Solving the $F$-type manager's objective function in equation (4) also yields $\beta_{F}(\phi)=$ $\phi$. The manager will exert this as long as both his utility and firm profits are positive. Under the assumption $\bar{U}>\frac{f-\eta}{2}$, the profit function cuts the payoff function from below and we only need to check for non-negative profits in order to understand when this behavior is optimal. This means solving for $\pi(\phi)=\eta+\phi^{2}-f=0$ yields that this is the optimal effort as long as $\phi \geq \sqrt{(f-\eta)}$. If $\phi<\sqrt{(f-\eta)}$, however, the manager can avoid losing the private benefit $\bar{U}$ by exerting a bit more effort and keeping the company alive. Making sure the firm's profits are non-negative, i.e., solving for $\beta$ in $\pi(\beta)=\eta+\phi \beta-f=0$ yields the effort function $\beta_{F}(\phi)=\frac{f-\eta}{\phi}$. Plugging the effort into the utility function, the payoff is $U_{F}(\phi)=\bar{U}-\frac{1}{2}\left(\frac{f-\eta}{\phi}\right)^{2}$. Under the assumption $\bar{U}>\frac{f-\eta}{2}$, this is strictly positive at $\phi=\sqrt{(f-\eta)}$ so the manager gains by choosing this effort level. However, if the initial productivity of the firm is too low, such that the payoff function even under this utility is zero, the firm exits. The exit cutoff can therefore be obtained from setting $U_{F}\left(\underline{\phi}_{F}\right)=0$ which yields $\underline{\phi}_{F}=\frac{f-\eta}{\sqrt{2 U}}$. The firm exits if the productivity draw is below $\phi_{F}$.

4. Notice that $\beta_{F}(\phi)=\frac{f-\eta}{\phi}$ is decreasing in $\phi$, while $\beta_{F}(\phi)=\phi$ is increasing in $\phi$.

\section{B.2 Proof of Proposition 2}

Proof. Consider the following:

1. As effort $\beta_{P}(\phi)=\phi$ increases in $\phi$, the realized productivity of $P$-type firms, $\beta_{P}(\phi) \phi$, also increases in $\phi$.

2. The same pattern holds for $F$-type firms, when $\phi \geq \sqrt{f-\eta}$. Realized productivity $\beta_{F}(\phi) \phi=f-\eta$ for $\phi \in\left[\phi_{F}, \sqrt{f-\eta}\right)$, i.e., constant. 
3. $P$-type firms have higher average realized productivity than $F$-type firms as $P$-type firms have a higher exit cutoff than $F$-type firms and realized productivity weakly increases in the initial productivity $\phi$ for both types of firms.

4. Note that for any value of realized productivity above $2(f-\eta)$ the corresponding value of the initial productivity draw is the same for $P$-type firms and $F$-type firms. Also note that only $F$-type firms have realized productivity below $(f-\eta)$. Since the initial productivity draw follows the same Pareto distribution for both $F$-type firms and $P$-type firms, the distribution of realized productivity of $P$-type firms first order stochastically dominates that of $F$-type firms.

\section{B.3 Proof of Proposition 3}

Proof. Consider:

1. Notice that both exit cutoffs (i.e., $\phi_{P}$ and $\phi_{F}$ ) are increasing functions of $\eta$ and therefore both exit cutoffs increase after import competition intensifies. However, both effort $\beta_{P}(\phi)=\phi$ and realized productivity $\phi \beta_{P}(\phi)$ of surviving $P$-type firms are independent of $\eta$, and therefore do not change after import competition increases.

2. For the same argument, effort and realized productivity of surviving $F$-type firms are independent of $\eta$ as long as productivity is high enough after the shock, i.e., $\phi \geq$ $\sqrt{f-\eta^{A}}$. However, effort below the kink $\sqrt{f-\eta^{A}}$ is an increasing function of $\eta$. For $F$-type firms with $\phi \in\left[\frac{f-\eta^{A}}{\sqrt{2 \bar{U}}}, \sqrt{f-\eta^{A}}\right)$, the manager's effort after the import shock is $\beta\left(\phi, \eta^{A}\right)=\frac{f-\eta^{A}}{\phi}$, while it was

$$
\beta_{F}\left(\phi, \eta^{B}\right)=\left\{\begin{array}{lll}
\phi & \text { if } & \phi \in\left[\sqrt{f-\eta^{B}}, \sqrt{f-\eta^{A}}\right) \\
\frac{f-\eta^{B}}{\phi} & \text { if } & \phi \in\left[\frac{f-\eta^{A}}{\sqrt{2 \bar{U}}}, \sqrt{f-\eta^{B}}\right)
\end{array}\right.
$$

before import competition increased.

As $\eta^{A}<\eta^{B}$, effort increases for $\phi \in\left[\frac{f-\eta^{A}}{\sqrt{2 \bar{U}}}, \sqrt{f-\eta^{A}}\right)$. Realized productivity is a positive function of effort for surviving firms, so realized productivity increases for these firms.

3. As only the realized productivity for initially unproductive surviving $F$-type firm increases, i.e., $\phi<\sqrt{f-\eta^{A}}$, and the realized productivity of all other firms are unchanged, the proposition follows directly. ${ }^{52}$

\footnotetext{
${ }^{52}$ Notice that, strictly speaking, we should not observe $P$-type firms that are as unproductive as those $F$-type firms that are increasing their productivity in the data. However, the real world is probably more complex than our stylized model: Either measurement error in productivity, a random component to realized productivity after exerting effort, or smaller fixed cost for $F$-type firms can generate the overlap in initial productivity among family and non-family firms that we see in the data while preserving the predictions of the model. For an example of how differential fixed costs effect predictions, see the figure and notes in the online appendix.
} 


\section{B.4 Proof of Proposition 4}

Proof. Consider the following:

1. The exit cutoff on the realized $\log$ productivity is $\phi_{P} \beta_{P}\left(\phi_{P}\right)=2(f-\eta)$ and $\phi_{F} \beta_{F}\left(\phi_{F}\right)=$ $f-\eta$ for $P$-type firms and $F$-type firms, respectively. As both cutoffs are decreasing functions of $\eta$, both cutoffs increase when import competition increases. Furthermore, the exit probability (either zero or one) decreases in the initially realized productivity, as firms exit if and only if their realized productivity is below the exit cutoff.

2. Note that the exit cutoff on realized productivity is always higher for $P$ type than for $F$ type firms. Therefore, $P$ type firms are more likely to exit than $F$ type firms when import competition increases, if both of them have the same initial realized productivity.

3. Note that firm profits equal $\eta+\phi \beta(\phi)-f$. As effort levels of all $P$-type firms are unchanged while $\eta$ decreases, profits of all $P$-type firms decrease. For $F$-type firms with productivity draws above $\sqrt{f-\eta^{A}}$, their effort levels are unchanged. Since $\eta$ decreases, profits of those initially productive $F$-type firms decrease in the same way as profits of $F$-type firms. Third, for $F$-type firms with productivity draws $\phi \in\left[\sqrt{f-\eta^{B}}, \sqrt{f-\eta^{A}}\right)$, they earn strictly positive profits before the reduction of import tariffs and zero profits after that. Thus, their profits drop. However, since their managers increase effort levels after the reduction of import tariffs, their profits drop less relative to $P$-type firms with the same productivity draws. Finally, for $F$-type firms with productivity draws $\phi \in\left[\frac{f-\eta^{A}}{\sqrt{2 \bar{U}}}, \sqrt{f-\eta^{B}}\right)$, they earn zero profits both before and after the reduction of import tariffs. Therefore, their profits do not change and increase relative to $P$-type firms with the same productivity draws (i.e., the initially least productive $P$-type firms). 